\title{
OPTIMATION PARAMETERS OF CNC MILLING PROGRAMMING MACHINE ON THE PROCESS TIME AND ITS EFFECT ON THE EFFICIENCY
}

\author{
Lydia Anggraini $^{1, a}$, Ivan Junixsen ${ }^{2, b}$ \\ ${ }^{1}$ Program Studi Teknik Mesin, Universitas Presiden, Jawa Barat, Indonesia \\ ${ }^{2}$ Program Sarjana Teknik Mesin, Universitas Presiden, Jawa Barat, Indonesia

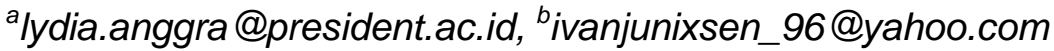

\begin{abstract}
Abstrak. Permasalahan yang diungkapkan dalam penelitian ini adalah tentang parameter Optimasi mesin pemrograman CNC milling pada waktu proses dan pengaruhnya terhadap efisiensi. Tujuan dari penelitian ini adalah untuk mengetahui pengaruh laju umpan, kedalaman potong, dan stepdown maksimum pada waktu pemrosesan dalam pemrograman milling CNC dan mencari parameter pemesinan terbaik yang menghasilkan waktu pemrosesan optimal pada pemrograman milling CNC. Hasilnya dapat berupa simulasi jarak pemesinan atau waktu operasi, panjang langkah umpan atau panjang potong umpan, dan panjang langkah tanpa pengumpanan atau panjang lintasan cepat. Data hasil percobaan digunakan untuk melihat pengaruh, dan kontribusi setiap parameter terhadap waktu proses pemesinan, juga kontribusi parameter yang dioptimalkan untuk setiap proses yang membuat waktu proses pemesinan penggilingan $\mathrm{CNC}$, dan biaya akan lebih efisien.
\end{abstract}

Kata kunci. Factorial test method

Abstract. The problems revealed in this research is about Optimization parameters of CNC milling programing machine on the process time and its effect on the efficiency. The purpose of this research are to know the effect of feed rate, depth of cut, and maximum stepdown on processing time in CNC milling programming and searching for the best machining parameters that yield optimal processing time on CNC milling programming. The result can be in the simulation of machining distance or operation time, length of feed step or feed cut length, and length of step without feeding or fast traverse length. Experiment result data is used for see the influence, and contribution of each parameter to the machining process time, also the contribution of the optimized parameters for each process that makes the CNC milling machining process time, and cost will be more efficient.

Keywords. Factorial test method

\section{PENDAHULUAN}

MasterCAM adalah pemrograman cam yang digunakan untuk membangun instruksi, dan dunia yang bermanfaat, di samping industri untuk klien organisasi teknik CNC yang mewajibkan ketelitian tentang teknik manufaktur mereka. Dengan menggunakan perangkat lunak MasterCAM, seorang programmer dapat mengubah parameter pemesinan yang menghasilkan durasi persiapan ideal waktu untuk memodifikasi pemrosesan CNC. Dalam hal ini, biaya proses pemesinan penggilingan CNC selama satu jam adalah Rp. 200.000, sehingga biaya untuk 1 menit proses pemesinan mesin CNC adalah Rp.3.400, dan harga alat yang digunakan untuk setiap proses pemesinan adalah Rp.78.500 


\section{METODOLOGI PENELITIAN}

In view of those foundation depiction of the problem, it will be referred to that the fundamental issue identified with those machining procedures of $\mathrm{CNC}$ processing is on the determination for machining parameters for example feed rate, maximum stepdown and depth of cut encourage rate Furthermore profundity from claiming reduced on $\mathrm{CNC}$ milling machining time, and machining cost.

\section{Objectives}

In accordance with the issues to be researched as formulated above, the objectives to be achieved in this study are:

1. Know the effect of feed rate on the processing time of CNC milling programming.

2. Knowing the influence of dept of cut of the processing time on $\mathrm{CNC}$ milling programming.

3. Knowing the effect of the maximum stepdown on the processing time on CNC milling programming.

4. Knowing machining parameters that produce optimal processing time on the CNC milling programming.

5. Calculating the most efficient machining time and machining cost.

\section{Study literature}

Calculation of the working time is the distance chisel multiplied by the frequency of feeding, divided by the speed of the feeding process times the speed [7]. Face vertical milling
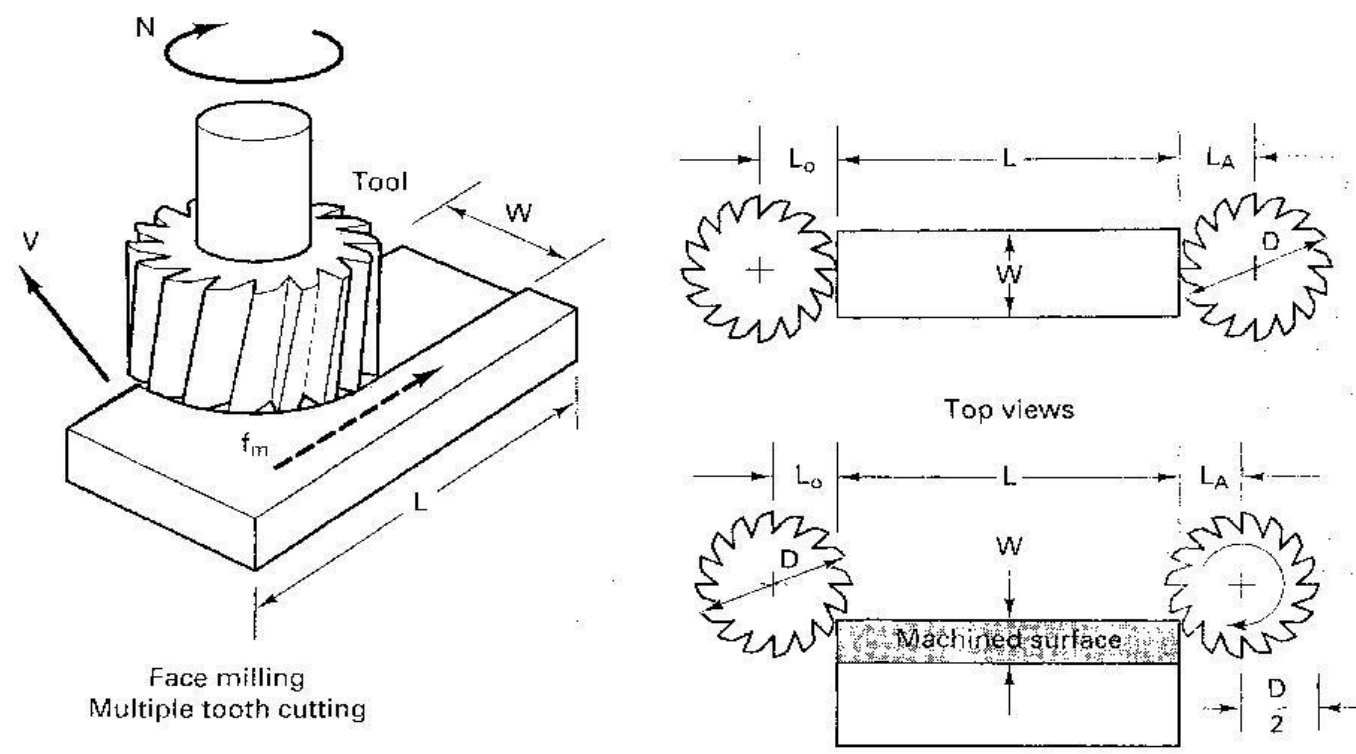

Figure 1 CNC milling process 
Journal of Mechanical Engineering and Mechatronics

ISSN: 2527-6212, Vol. 3 No. 2

(C) 2018 Pres Univ Press Publication, Indonesia

\section{MasterCAM 9.1 software}

CAD / CAM stands for Computer-Aided Design and Computer- Aided Manufacturing. The

CAD / CAM application is used to design a machine part and create a CNC program for its processing [1].

\section{Research methodology}

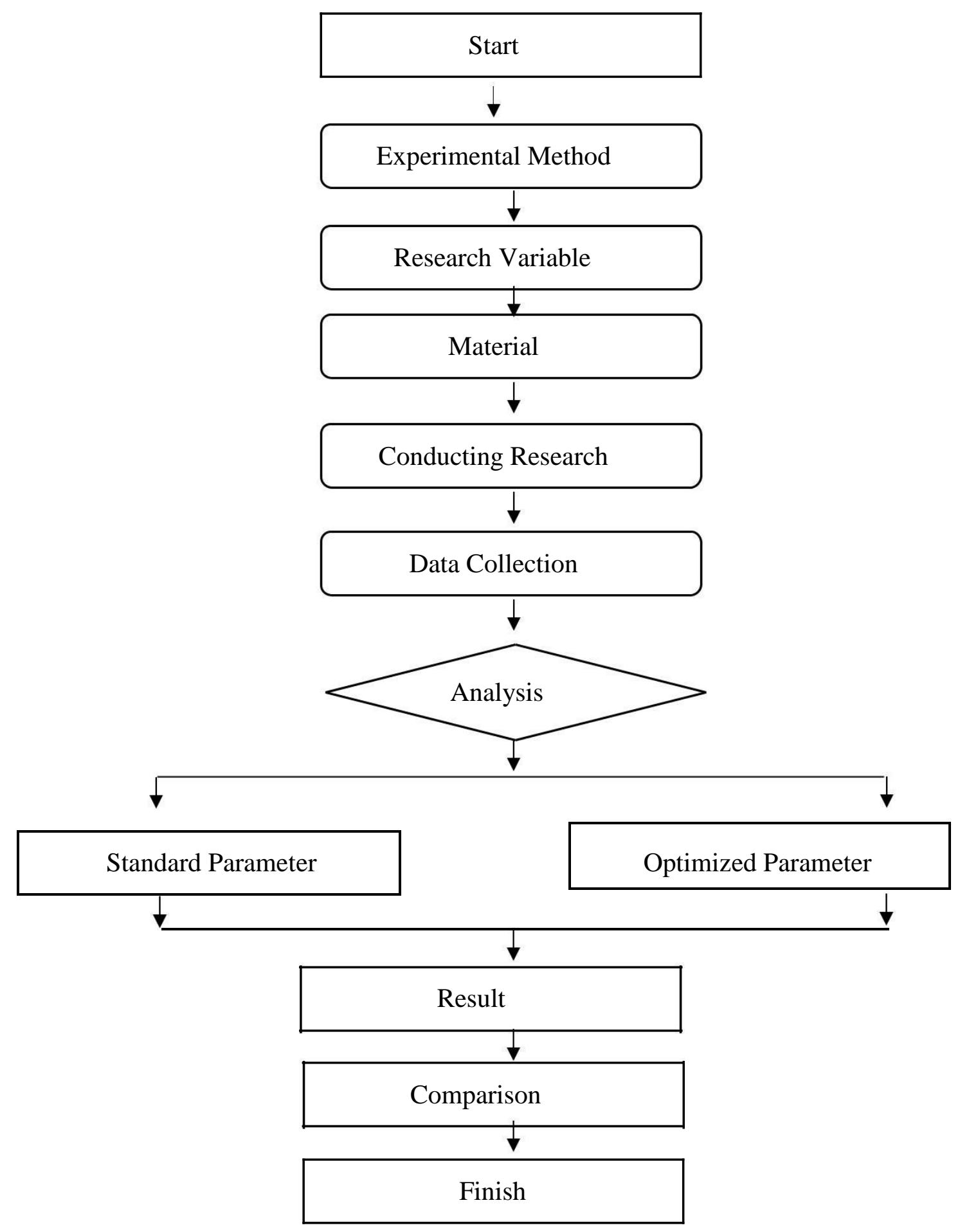

Figure 1 Flow chart diagram 
Journal of Mechanical Engineering and Mechatronics

ISSN: 2527-6212, Vol. 3 No. 2

(C) 2018 Pres Univ Press Publication, Indonesia

III. HASIL, PEMBAHASAN DAN ANALISA

Experiment parameters data

Table 1 Drill parameters data

\begin{tabular}{|c|c|c|c|}
\hline $\begin{array}{c}\text { Feed rate } \\
(\mathrm{mm} / \mathrm{rev})\end{array}$ & $\begin{array}{c}\text { Machining time } \\
(\mathrm{min})\end{array}$ & Machining cost & Depth of cut $(\mathrm{mm})$ \\
\hline 50 & 12 & $\mathrm{Rp} \mathrm{40,800}$ & 5 \\
\hline 60 & 10 & $\mathrm{Rp} \mathrm{34,000}$ & 10 \\
\hline 70 & 8 & $\mathrm{Rp} \mathrm{27,200}$ & 15 \\
\hline
\end{tabular}

Table 2 Facing parameters data

\begin{tabular}{c|c|c|c|}
\hline $\begin{array}{c}\text { Feed rate } \\
(\mathrm{mm} / \mathrm{rev})\end{array}$ & $\begin{array}{c}\text { Machining time } \\
(\mathrm{min})\end{array}$ & Machining cost & $\begin{array}{c}\text { Max rough } \\
\text { stepdown (mm) }\end{array}$ \\
\hline 1000 & 1.43333 & $\mathrm{Rp} \mathrm{4,873}$ & 2 \\
\hline 1200 & 1.21667 & $\mathrm{Rp} \mathrm{4,137}$ & 4 \\
\hline 1400 & 1.05 & $\mathrm{Rp} \mathrm{3,570}$ & 6 \\
\hline
\end{tabular}

Table 3 Surface rough pocket parameters data

\begin{tabular}{|c|c|c|c|}
\hline $\begin{array}{c}\text { Feed rate } \\
(\mathrm{mm} / \mathrm{rev})\end{array}$ & $\begin{array}{c}\text { Machining time } \\
(\mathrm{min})\end{array}$ & Machining cost & $\begin{array}{c}\text { Maximum } \\
\text { stepdown }(\mathrm{mm})\end{array}$ \\
\hline 1500 & 145 & $\mathrm{Rp} \mathrm{493,000}$ & 0.5 \\
\hline 1700 & 43 & $\mathrm{Rp} \mathrm{146,200}$ & 1.5 \\
\hline 1900 & 23 & $\mathrm{Rp} \mathrm{78,200}$ & 2.5 \\
\hline
\end{tabular}

\section{Material and tool}

Material: SKD 11

Table 1 Misumi Material Catalog [4]

\begin{tabular}{|c|c|c|c|}
\hline Material & $\begin{array}{c}\text { Heat Treatment } \\
\left({ }^{\circ} \mathrm{C}\right)\end{array}$ & Hardness & $\begin{array}{c}\text { Specific Gravity } \\
(\text { at 20 }\end{array}$ \\
\hline SKD11 & $\begin{array}{c}\text { Hardened 1000 }- \\
\text { 1050 Air cooled }\end{array}$ & $58-63 \mathrm{HRC}$ & 7.8 \\
\hline SKD11 & $\begin{array}{c}\text { Tempered 150 }- \\
\text { 200 Air cooled }\end{array}$ & $59-63 \mathrm{HRC}$ & 7.8 \\
\hline
\end{tabular}

Tool: Mitsubishi Hitachi

Table 2 Mitsubishi Hitachi tool Catalog [5]

\begin{tabular}{|c|c|}
\hline Tool & Drill \\
\hline Revolution & $950 \mathrm{rpm}$ \\
\hline Drilling depth & $16 \mathrm{~mm}$ max \\
\hline Feed rate & $100 \mathrm{~mm} / \mathrm{rev} \max$ \\
\hline
\end{tabular}

Table 3 Mitsubishi Hitachi tool Catalog [5]

\begin{tabular}{|c|c|} 
Tool & End Mill \\
\hline Revolution & $1000 \mathrm{rpm}$ \\
\hline Drilling depth & $15 \mathrm{~mm}$ max \\
\hline Feed rate & $1800 \mathrm{~mm} / \mathrm{rev} \max$ \\
\hline
\end{tabular}


Journal of Mechanical Engineering and Mechatronics

ISSN: 2527-6212, Vol. 3 No. 2

(C) 2018 Pres Univ Press Publication, Indonesia

\section{Conducting research}

Drill process

a. Start master cam v9 lathe

b. Open the design picture

c. Choose the toolpaths (the path through space that the tip of a cutting tool follows on its way to producing the desired geometry of the workpiece).

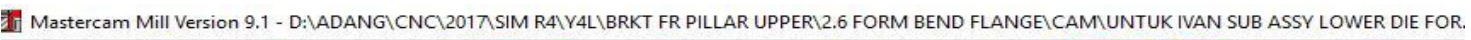

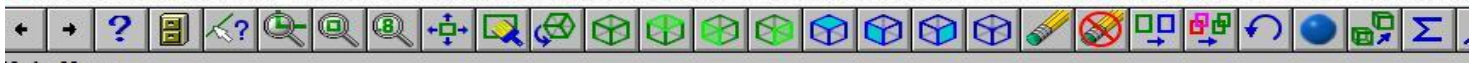
Main Menu: Analyze Create File

Modify

Xform

Delete

Screen

Solids

Ioolpath

NC utils

BACKUP

MAIN MENU

Z: 0.000

Color:

Attributes

Attributes

Mask: OFF

WCS: $T$

Tplane: $T$

Cplane: $T$

Gview: T

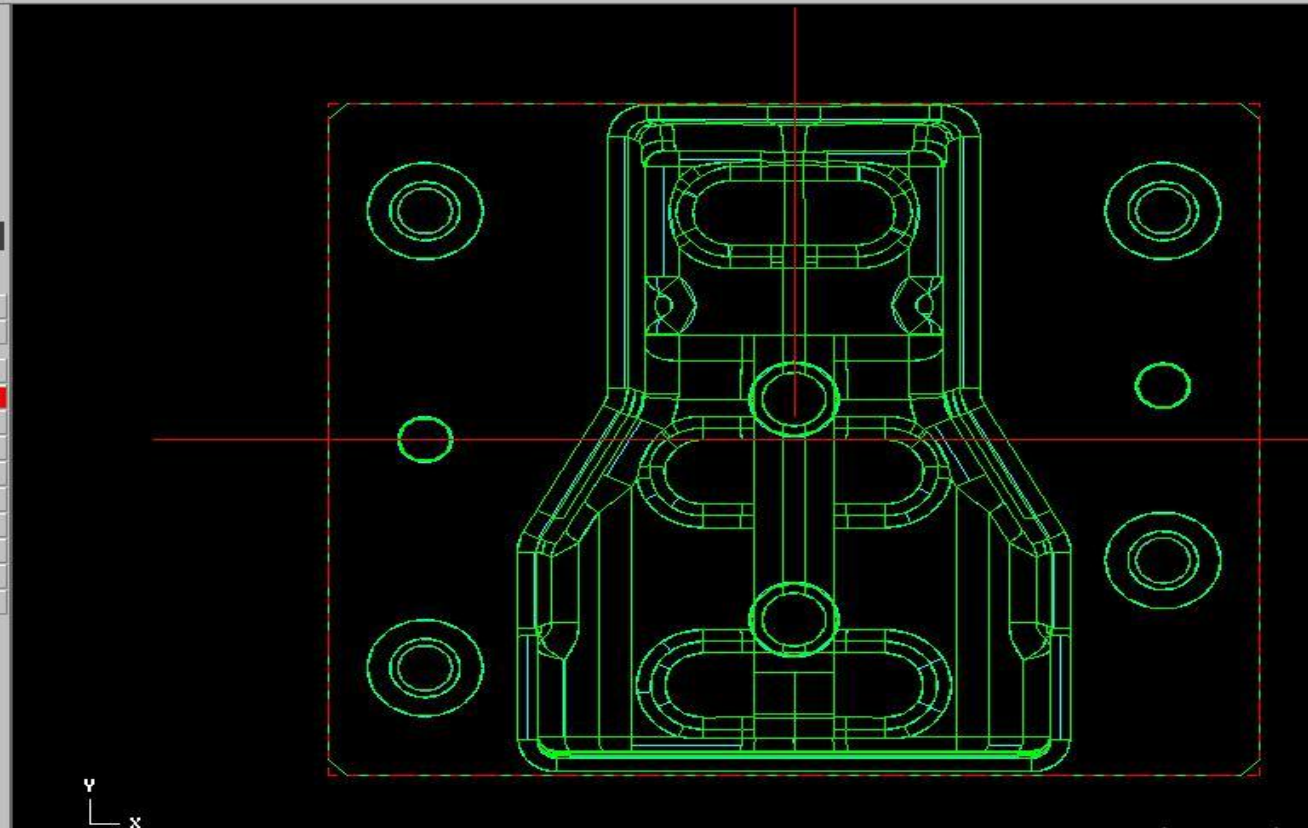


Journal of Mechanical Engineering and Mechatronics

ISSN: 2527-6212, Vol. 3 No. 2

(c) 2018 Pres Univ Press Publication, Indonesia

d. Choose drill option for machining process

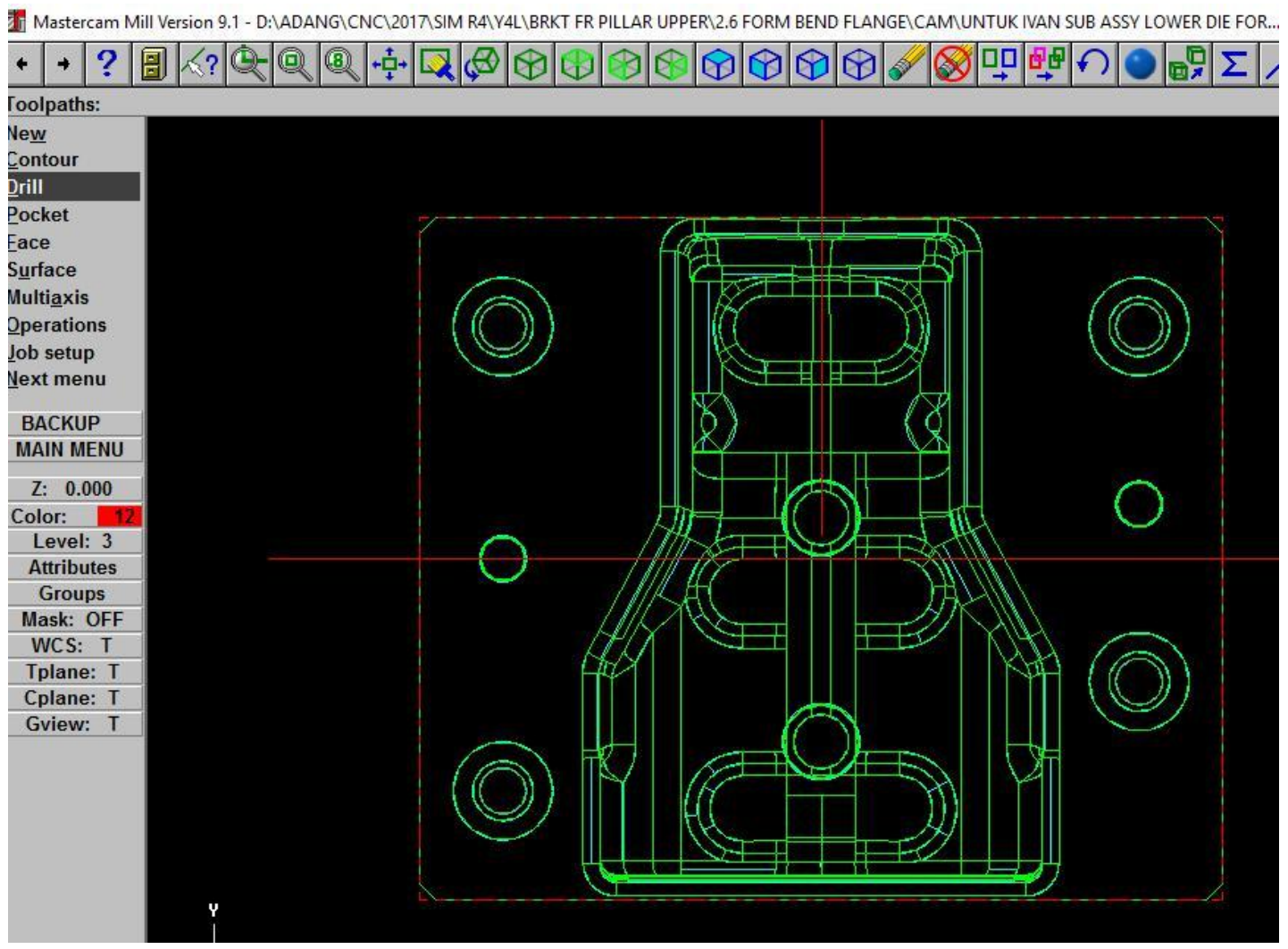

e. Click on the manual option

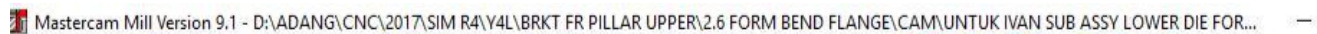

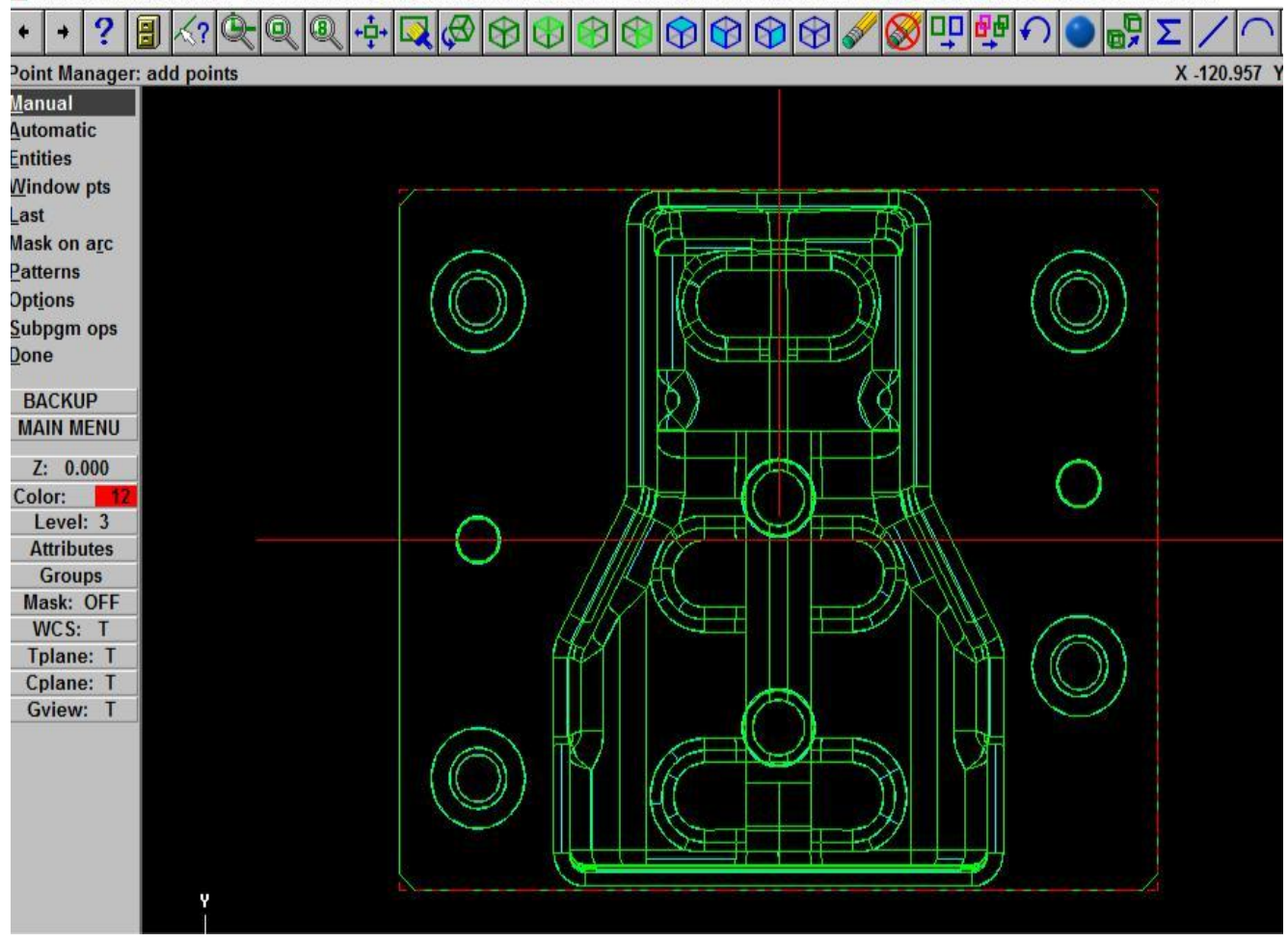


Journal of Mechanical Engineering and Mechatronics

ISSN: 2527-6212, Vol. 3 No. 2

(C) 2018 Pres Univ Press Publication, Indonesia

f. Choose the hole on the design picture sketch

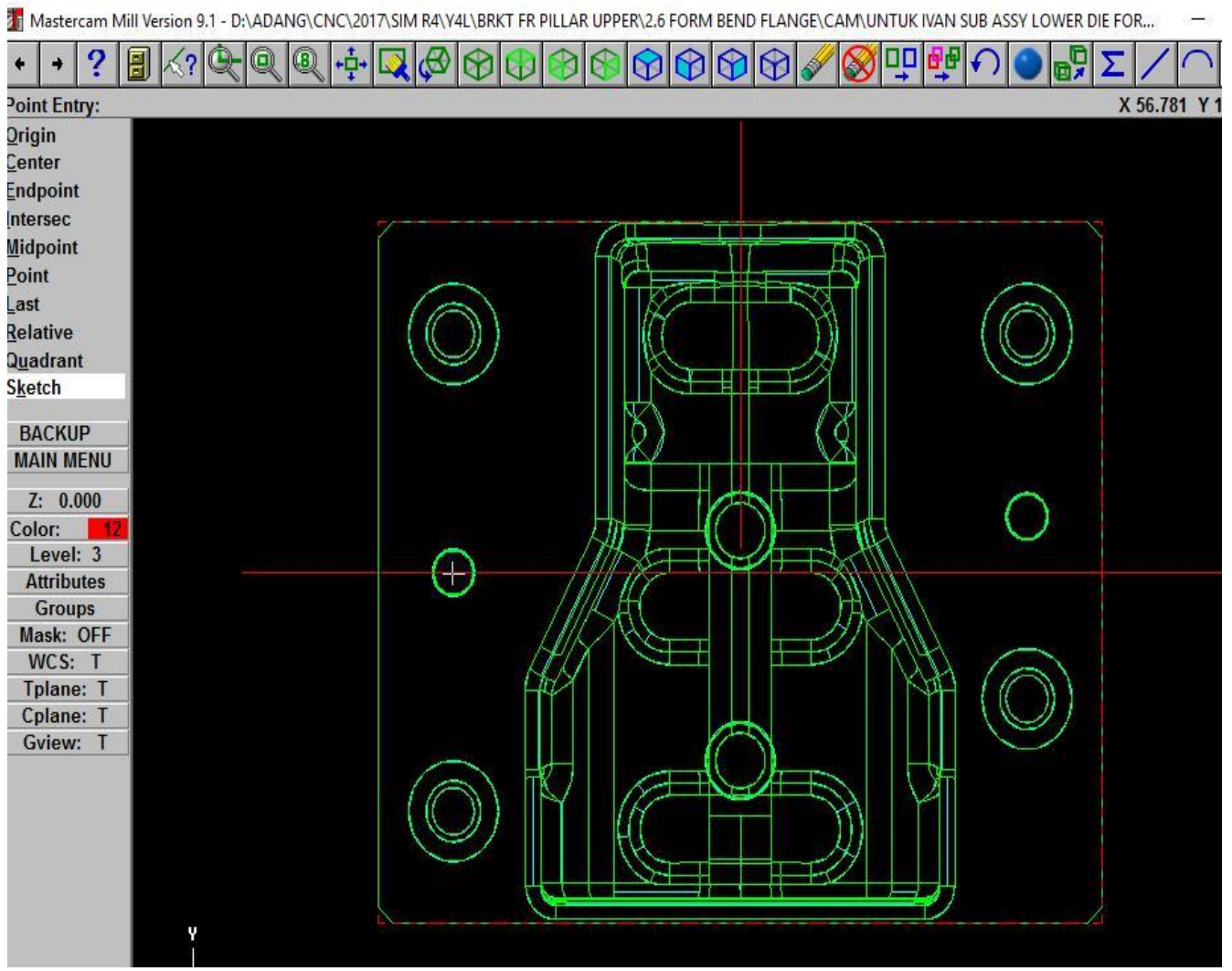

\section{g. Click done}

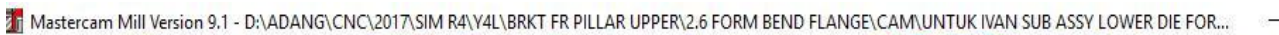

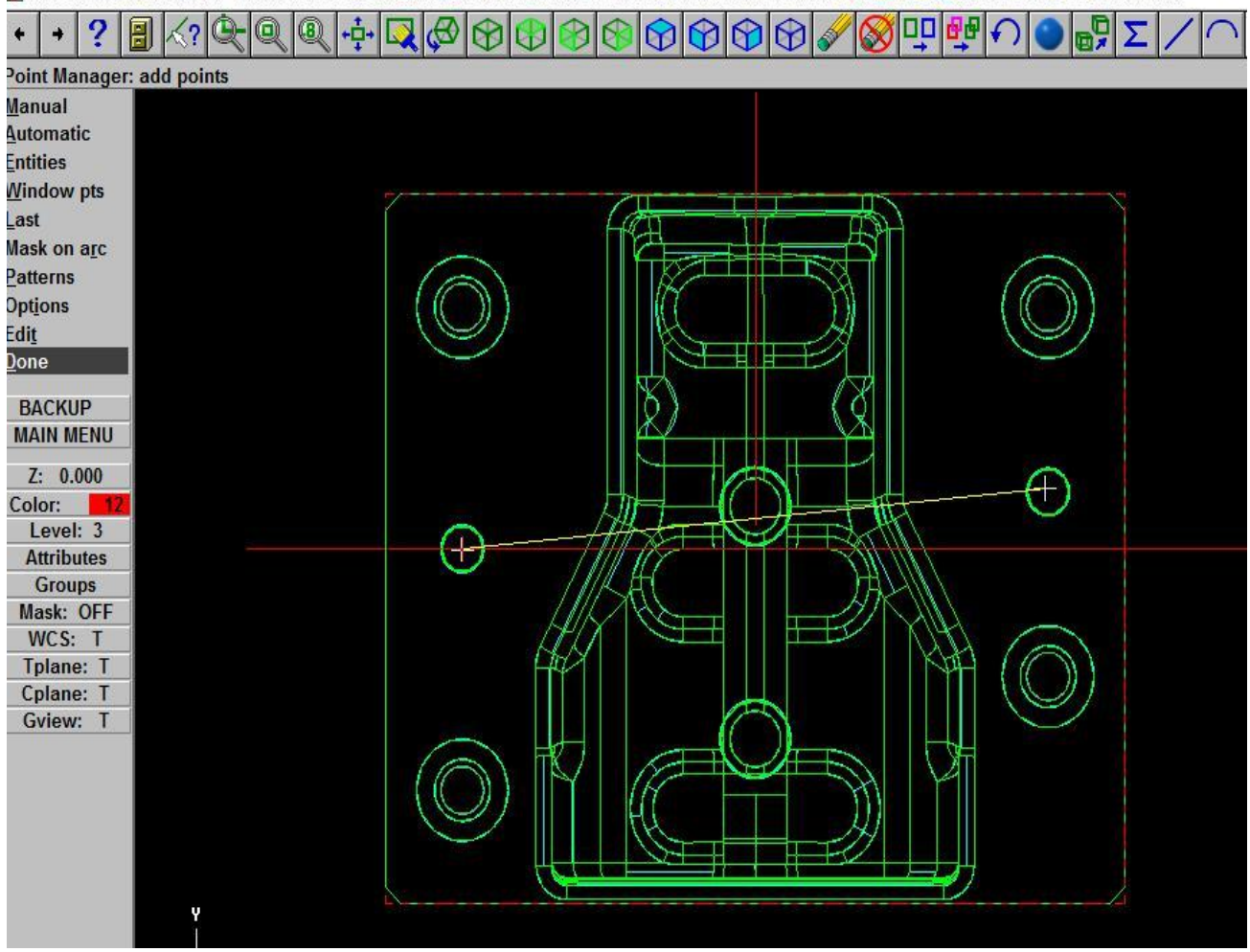


Journal of Mechanical Engineering and Mechatronics

ISSN: 2527-6212, Vol. 3 No. 2

(c) 2018 Pres Univ Press Publication, Indonesia

h. Create new tool for the machining process

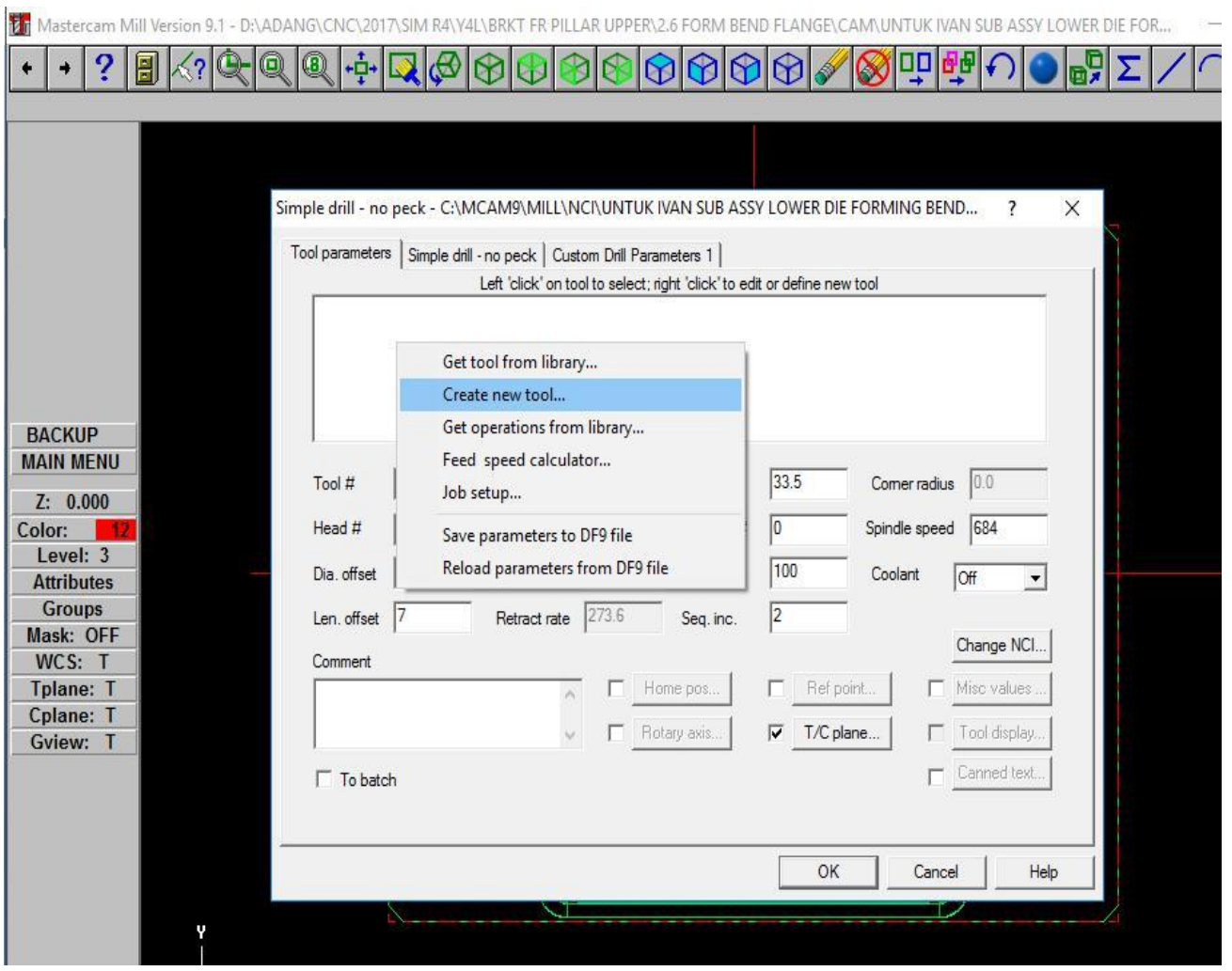

i. Define the tool type that want to be used for machining process

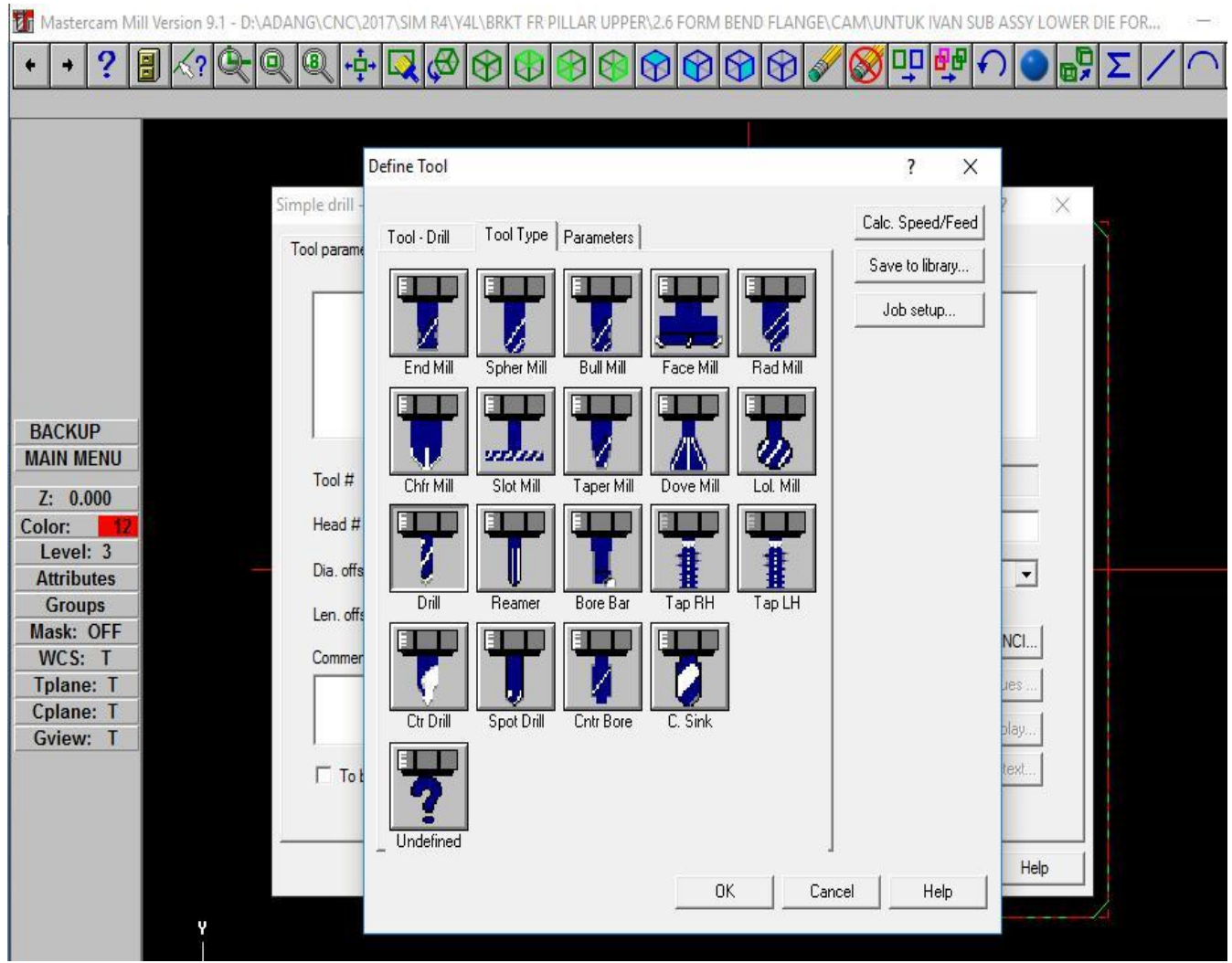


Journal of Mechanical Engineering and Mechatronics

ISSN: 2527-6212, Vol. 3 No. 2

(c) 2018 Pres Univ Press Publication, Indonesia

j. Set the diameter of the tool that needed for the tool that used

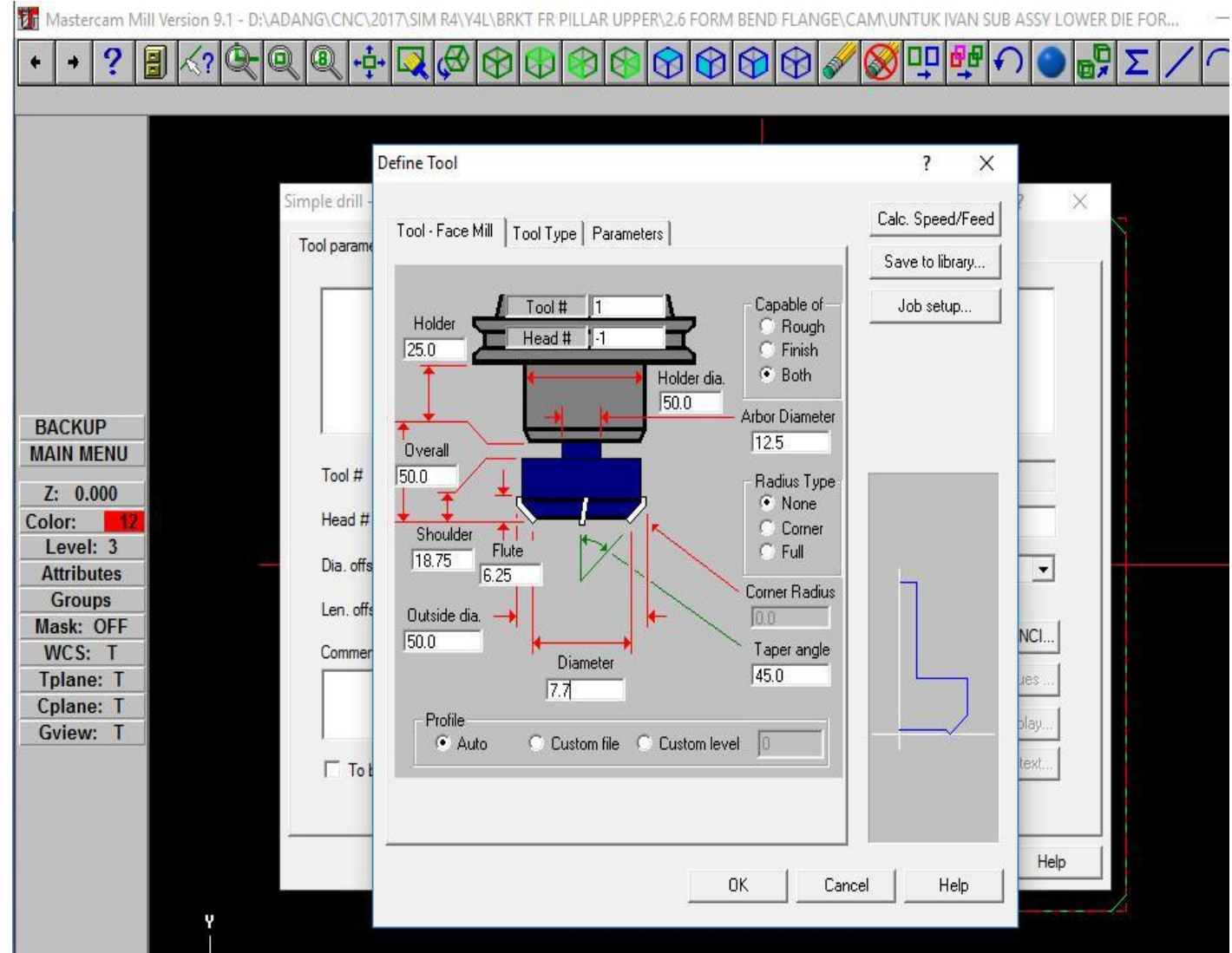

k. Set the clearance, absolute top of stock, and depth of cut

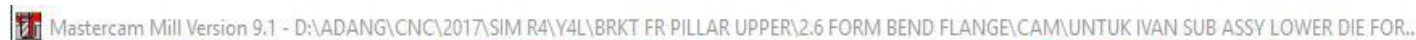

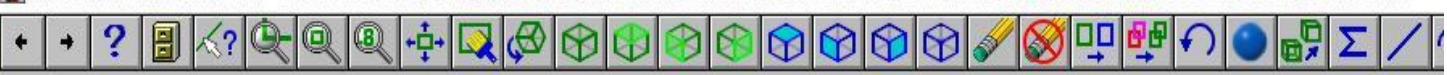

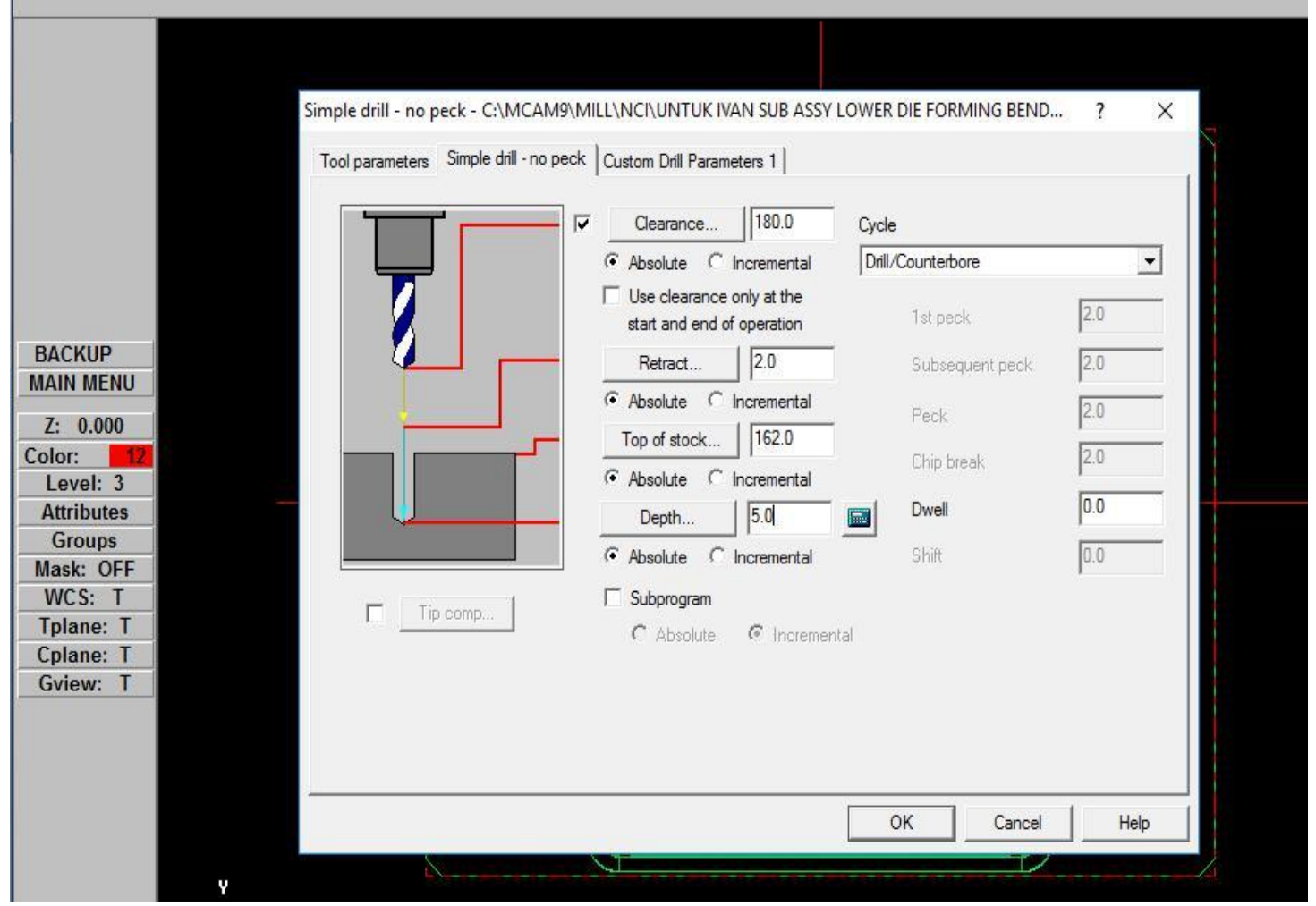


Journal of Mechanical Engineering and Mechatronics

ISSN: 2527-6212, Vol. 3 No. 2

(C) 2018 Pres Univ Press Publication, Indonesia

Facing

a. Start master cam v9 lathe

b. Open the design picture

c. Choose the toolpaths (the path through space that the tip of a cutting tool follows on its way to producing the desired geometry of the workpiece)

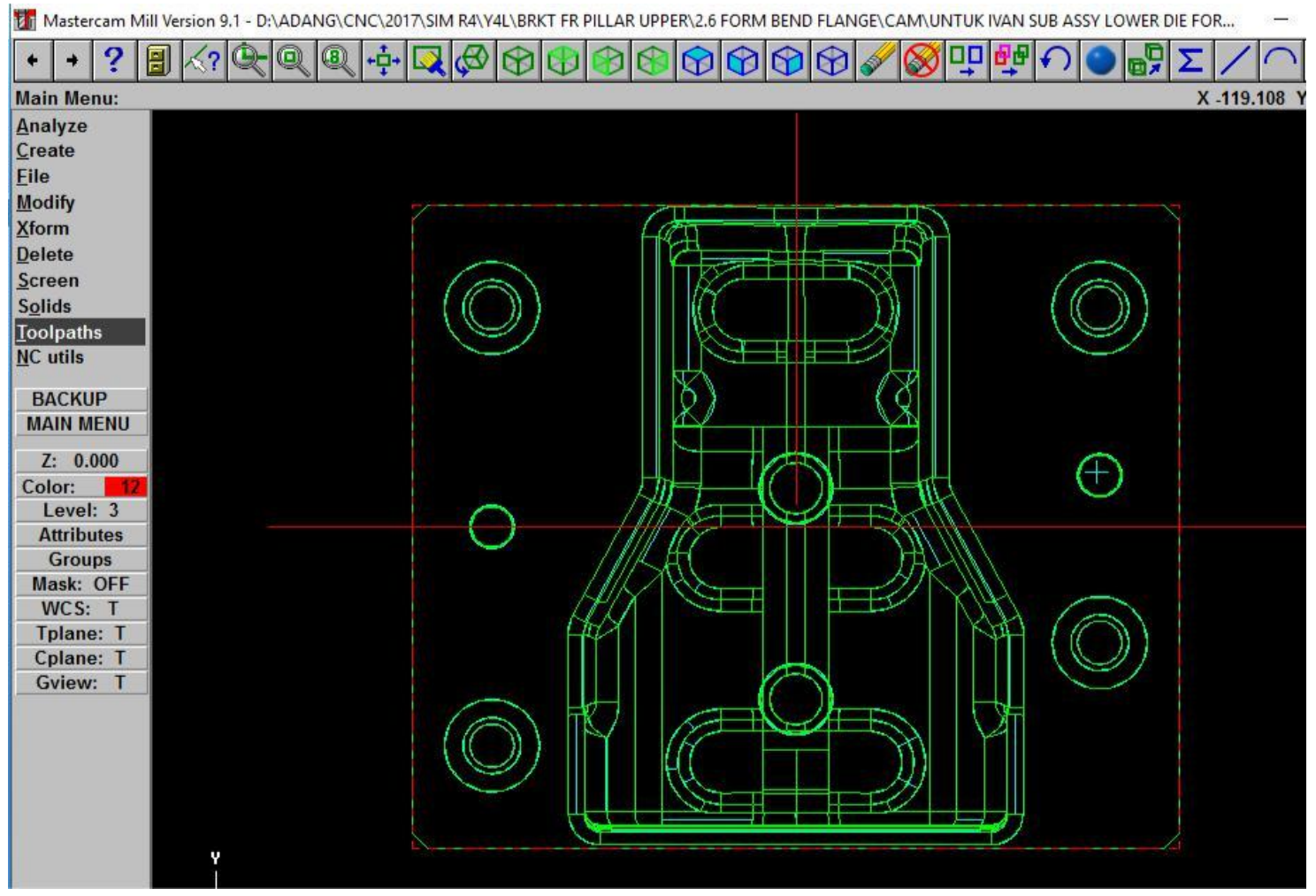


Journal of Mechanical Engineering and Mechatronics

ISSN: 2527-6212, Vol. 3 No. 2

(c) 2018 Pres Univ Press Publication, Indonesia

\section{d. Click face option for the facing machining process}

Mastercam Mill Version 9.1 - D:IADANG CNCI2017 SIM R4\Y4L\BRKT FR PILLAR UPPERI2.6 FORM BEND FLANGEICAM UNTUK IVAN SUB ASSY LOWER DIE FOR...

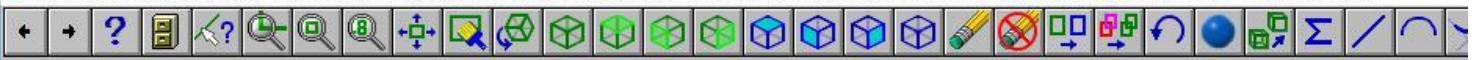
Toolpaths: New Contour Drill

Pocket Face Surface Multiaxis Operations Job setup Next menu BACKUP MAIN MENU Z: 0.000 Color: 11 Level: 3 Attributes Mask: OFF WCS: T Tplane: $T$ Cplane: $\mathrm{T}$ Gview: T

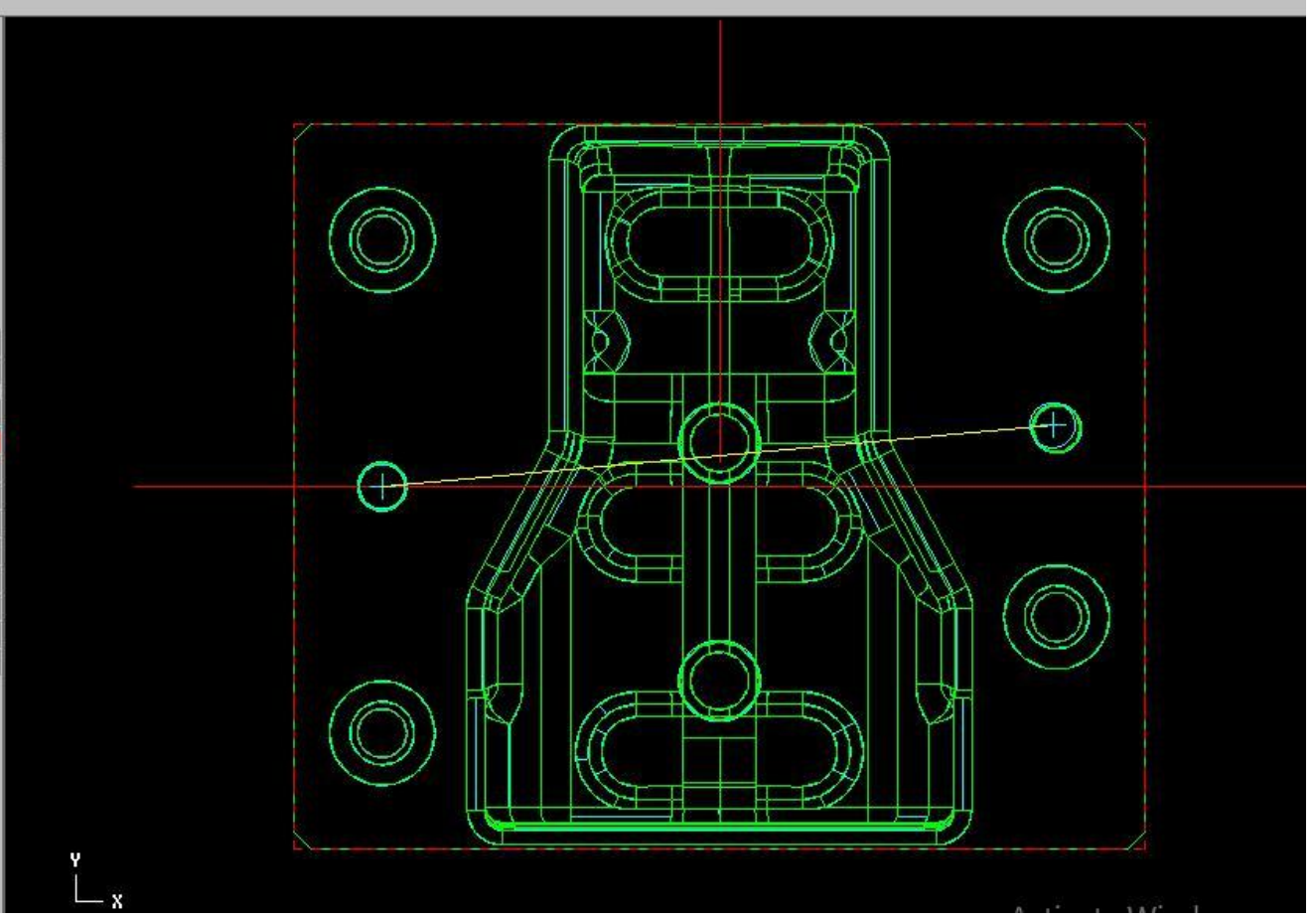

e. Choose on the chain option

Mastercam Mill Version 9.1 - D:IADANGICNCI2017 SIM R4 YY4LLBRKT FR PILLAR UPPERI2.6 FORM BEND FLANGEICAMIUNTUK IVAN SUB ASSY LOWER DIEF

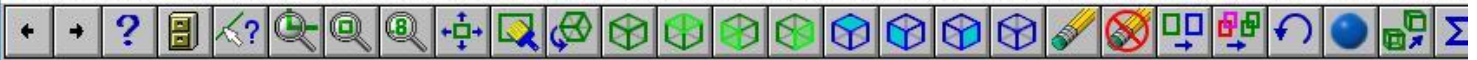
Face: select Done to use defined stock or select chain 1

Chain

Window

Area

Single

Section

Solids

Last

Unselect

Done

\section{BACKUP}

MAIN MENU

Z: 0.000

Color:

Level: 3

Attributes

Groups

Mask: OFF

WCS: T

Tplane: $T$

Cplane: T

Gview: $T$

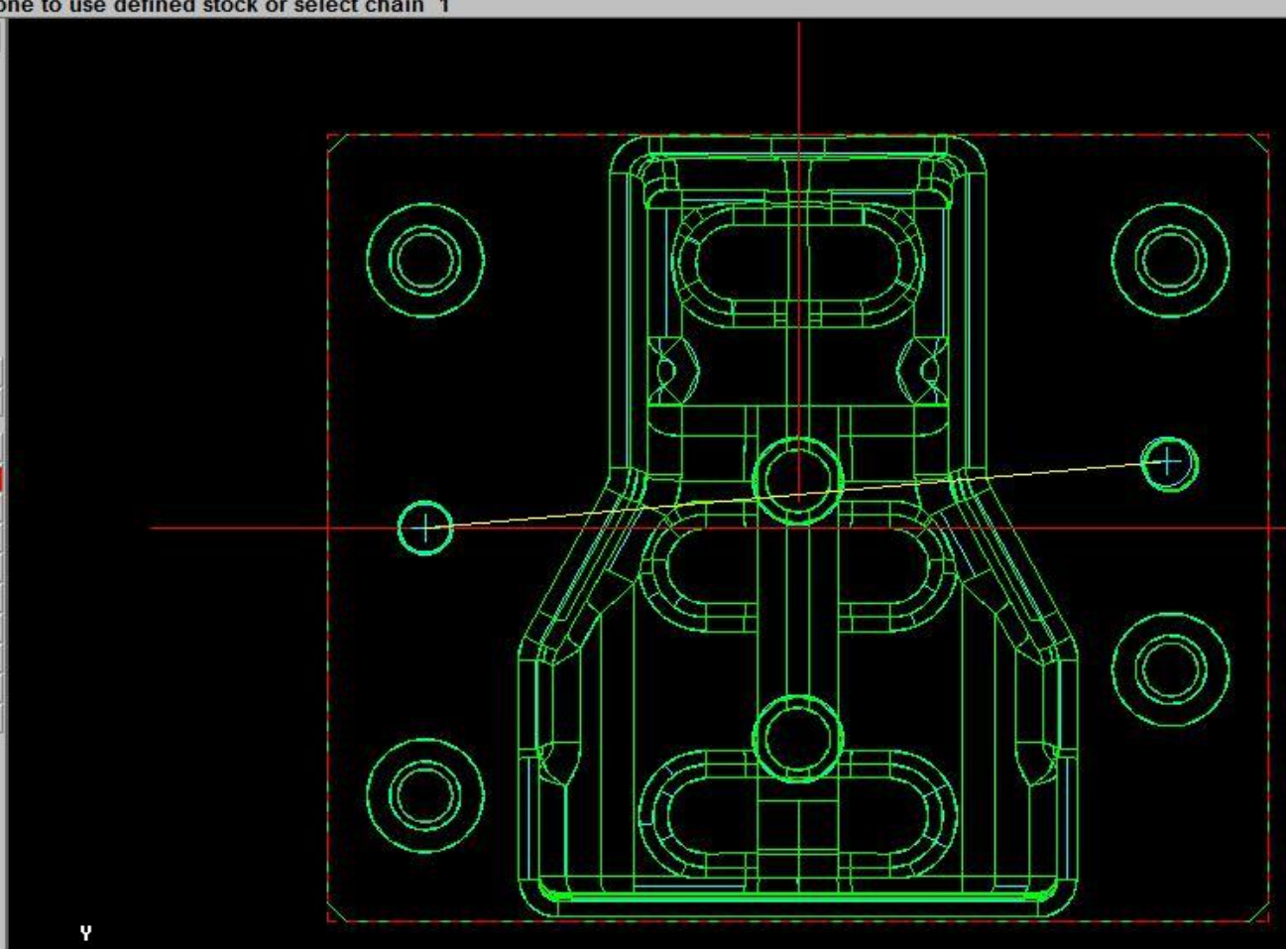


Journal of Mechanical Engineering and Mechatronics

ISSN: 2527-6212, Vol. 3 No. 2

(c) 2018 Pres Univ Press Publication, Indonesia

\section{f. Click done}

1. Mastercam Mill Version 9.1 - D:IADANGICNCI2017 SIM R4IY4LIBRKT FR PILLAR UPPERI2.6 FORM BEND FLANGEICAMMUNTUK IVAN SUB ASSY LOWER DIE FOR.... - $\quad$ -

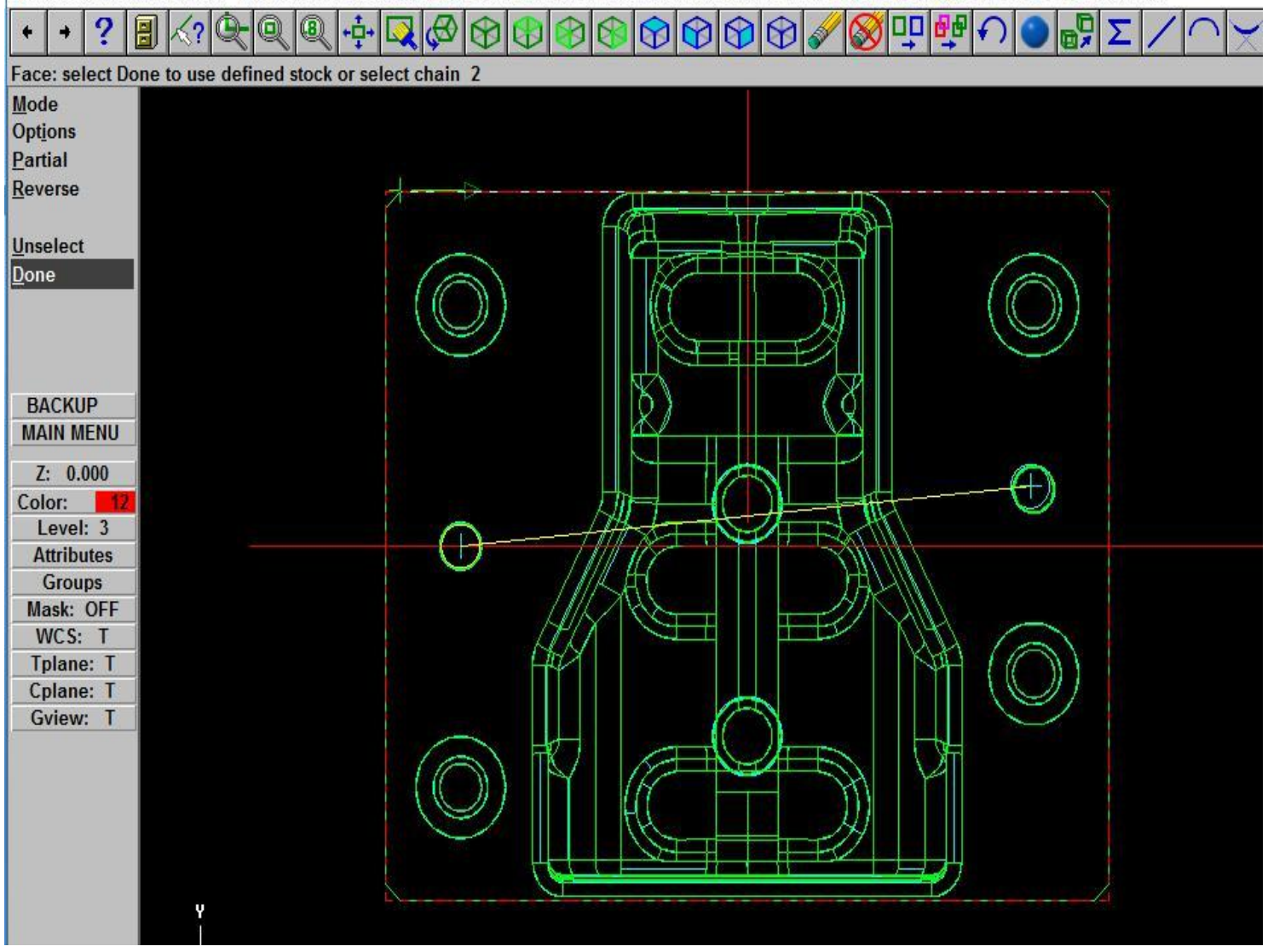

g. Create new tool for the machining process

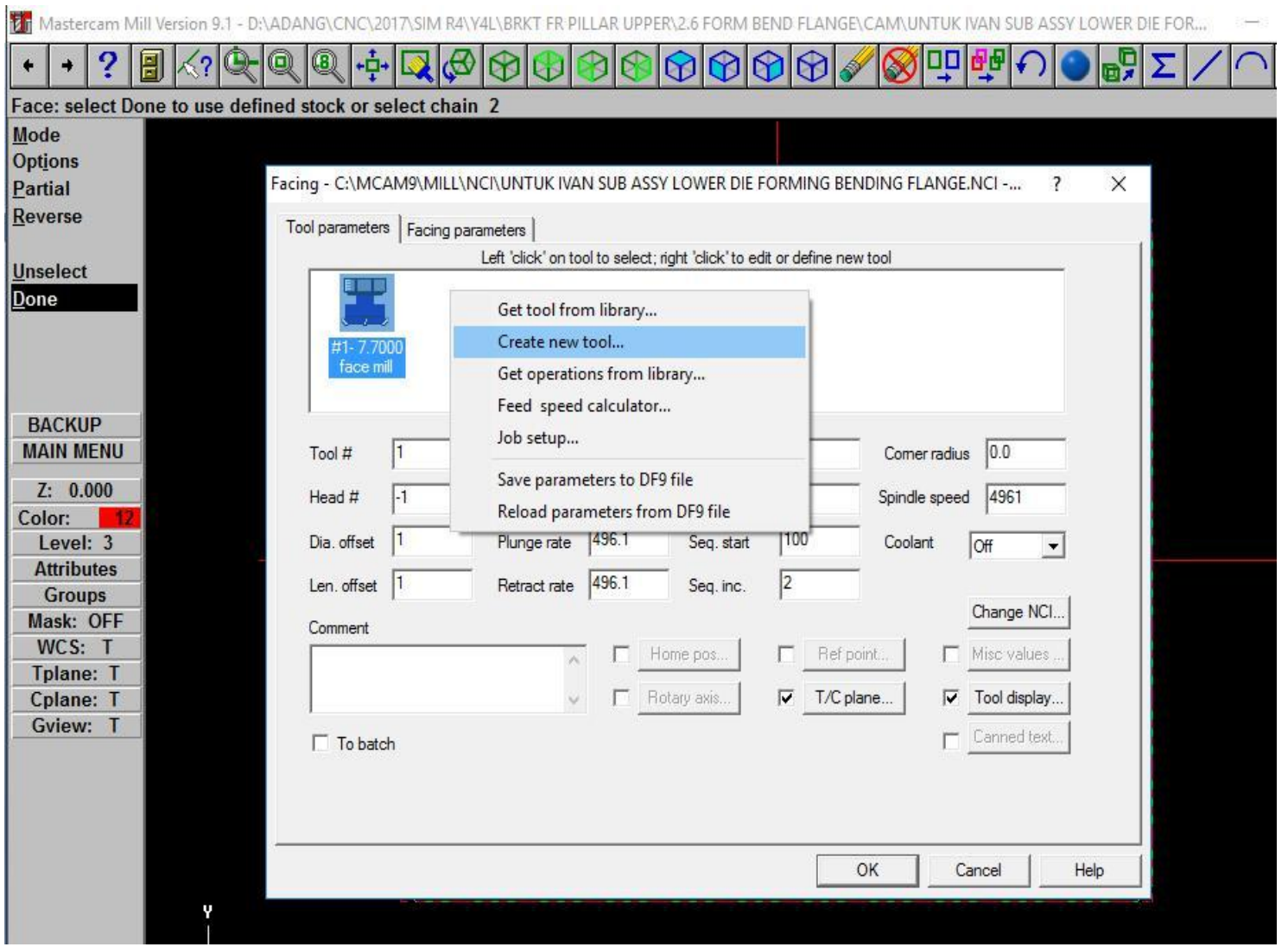


Journal of Mechanical Engineering and Mechatronics

ISSN: 2527-6212, Vol. 3 No. 2

(C) 2018 Pres Univ Press Publication, Indonesia

h. Define the tool type that want to be used for machining process

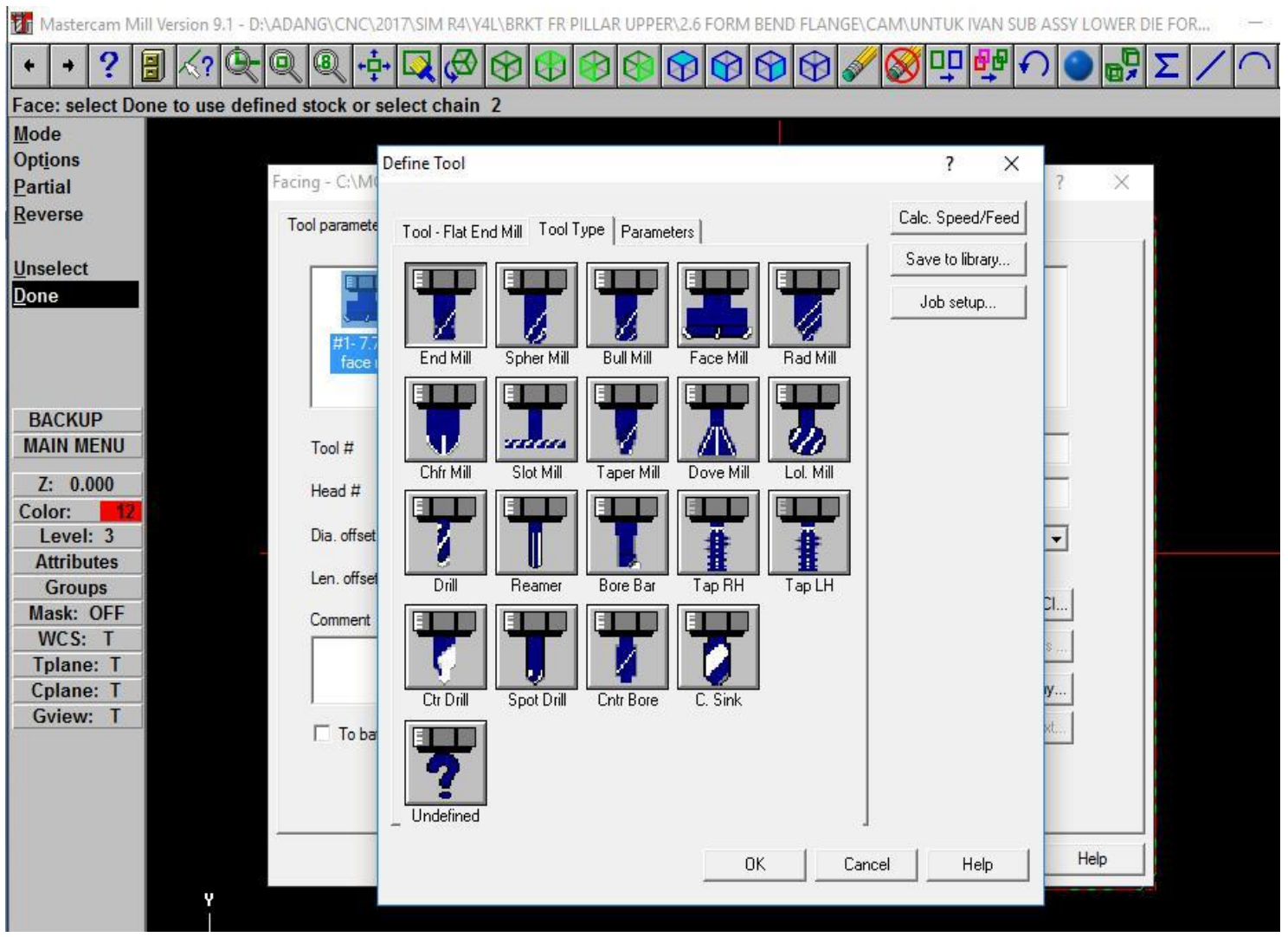

i. Set the diameter of the tool that needed for machining process

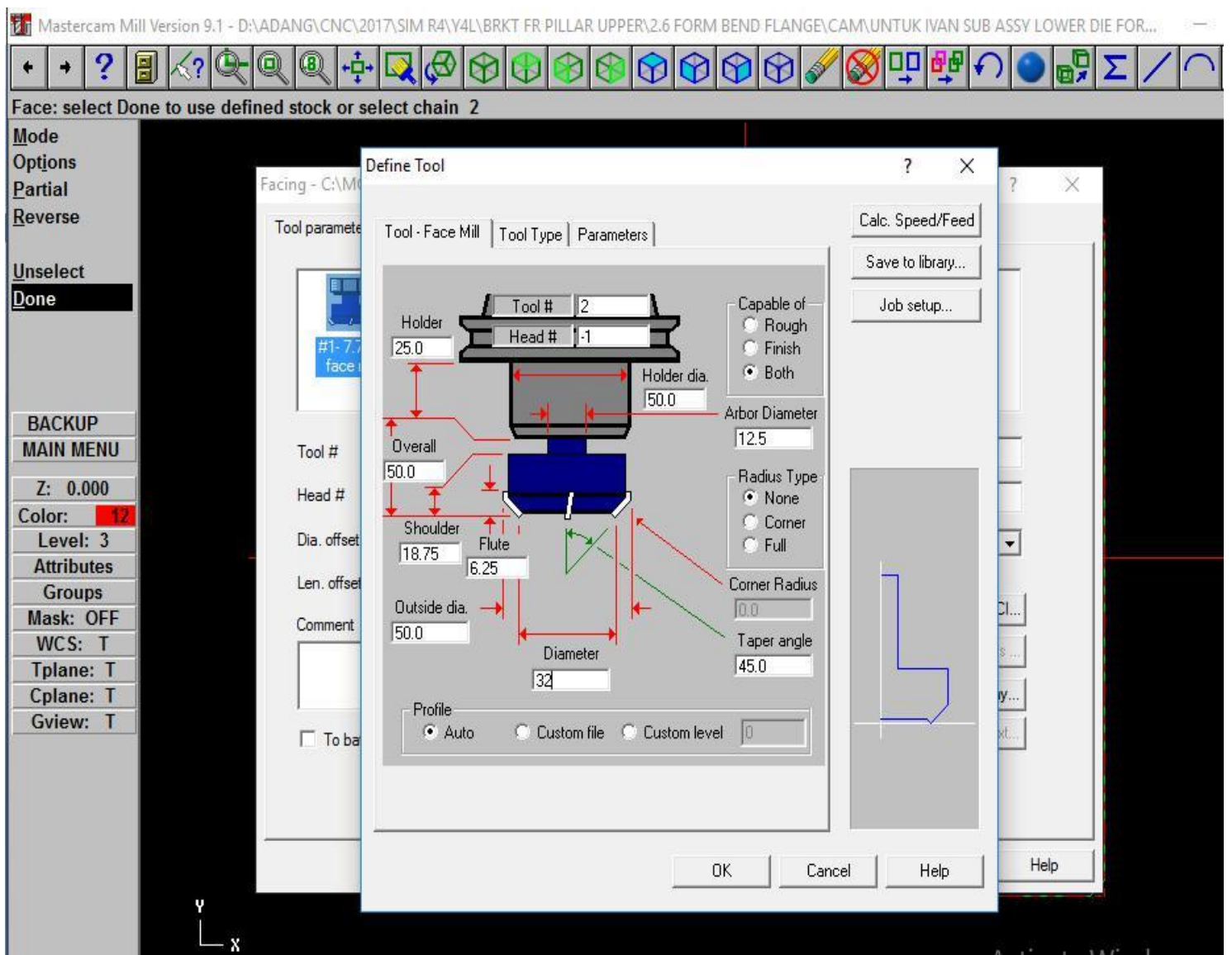


Journal of Mechanical Engineering and Mechatronics

ISSN: 2527-6212, Vol. 3 No. 2

(c) 2018 Pres Univ Press Publication, Indonesia

j. Set the clearance, and depth of cut on the maximum rough step

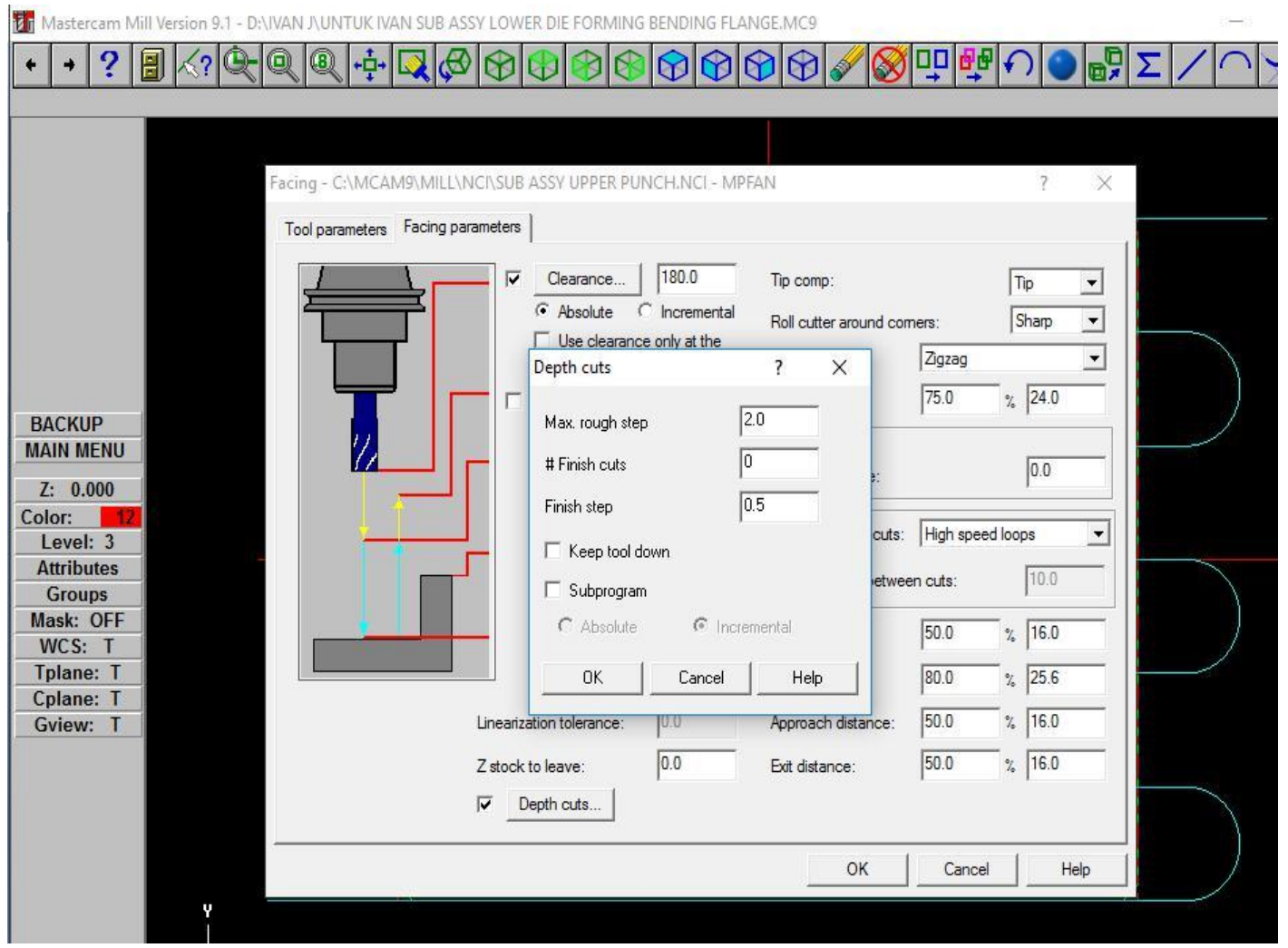

Surface rough pocket

a. Start master cam v9 lathe

b. Open the design picture

c. Choose the toolpaths (the path through space that the tip of a cutting tool follows on its way to producing the desired geometry of the workpiece)

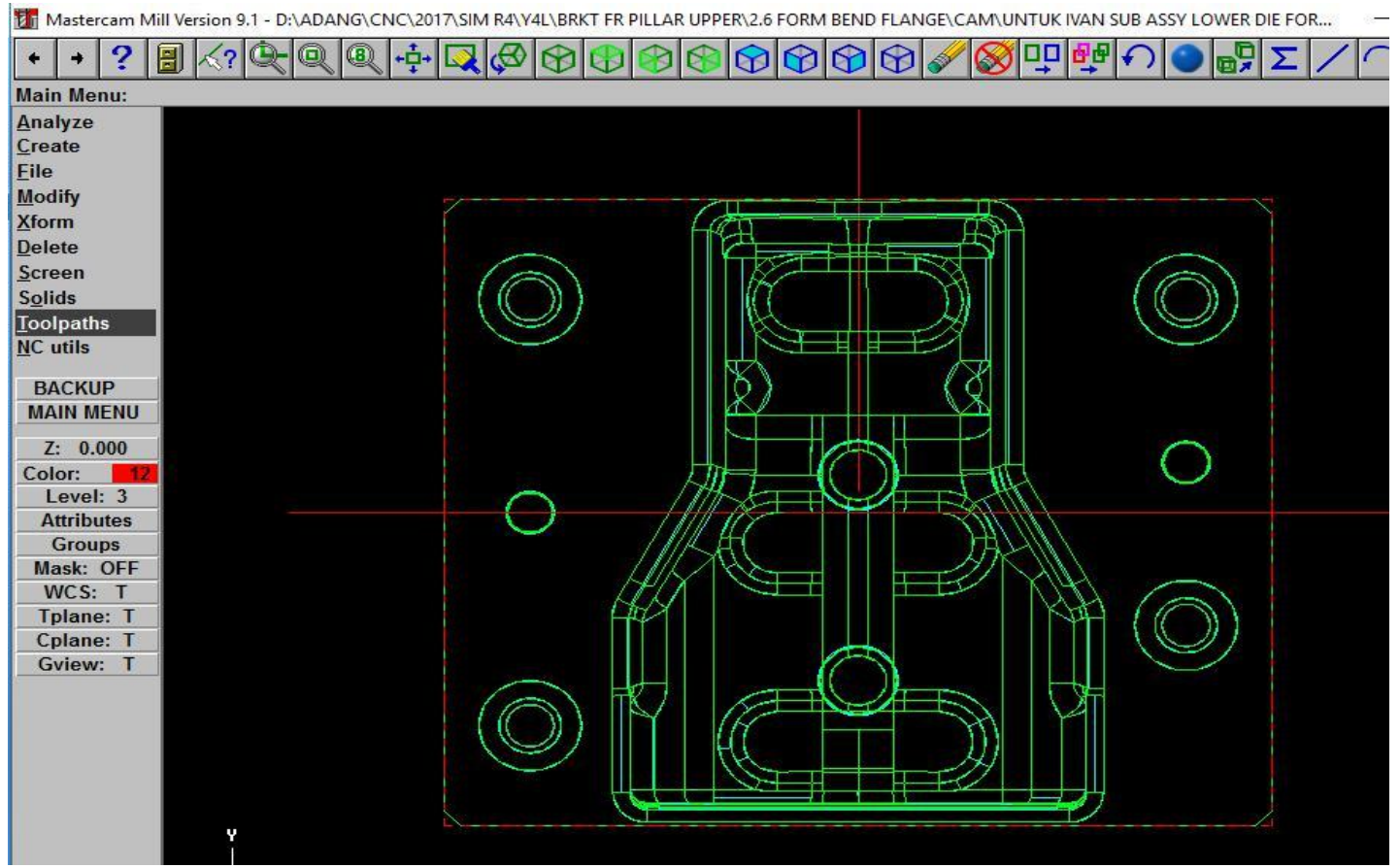


Journal of Mechanical Engineering and Mechatronics

ISSN: 2527-6212, Vol. 3 No. 2

(C) 2018 Pres Univ Press Publication, Indonesia

d. Choose the surface that want to be proceed

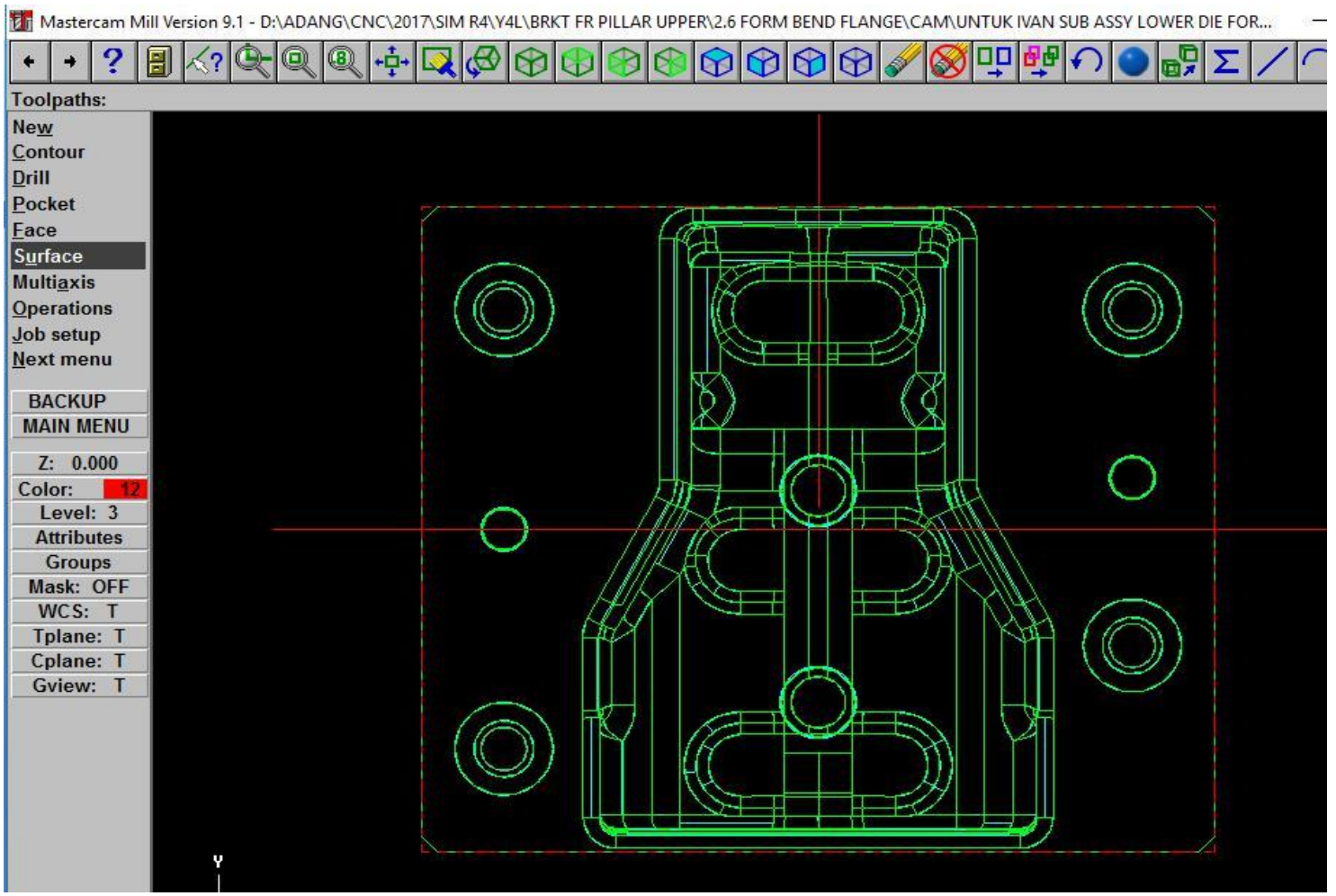

e. Click on the rough option

Mastercam Mill Version 9.1 - D:IADANGICNCI2017 SIM R4IY4LLBRKT FR PILLAR UPPERI2.6 FORM BEND FLANGEICAMIUNTUK IVAN SUB ASSY LOWER DIE FOR...

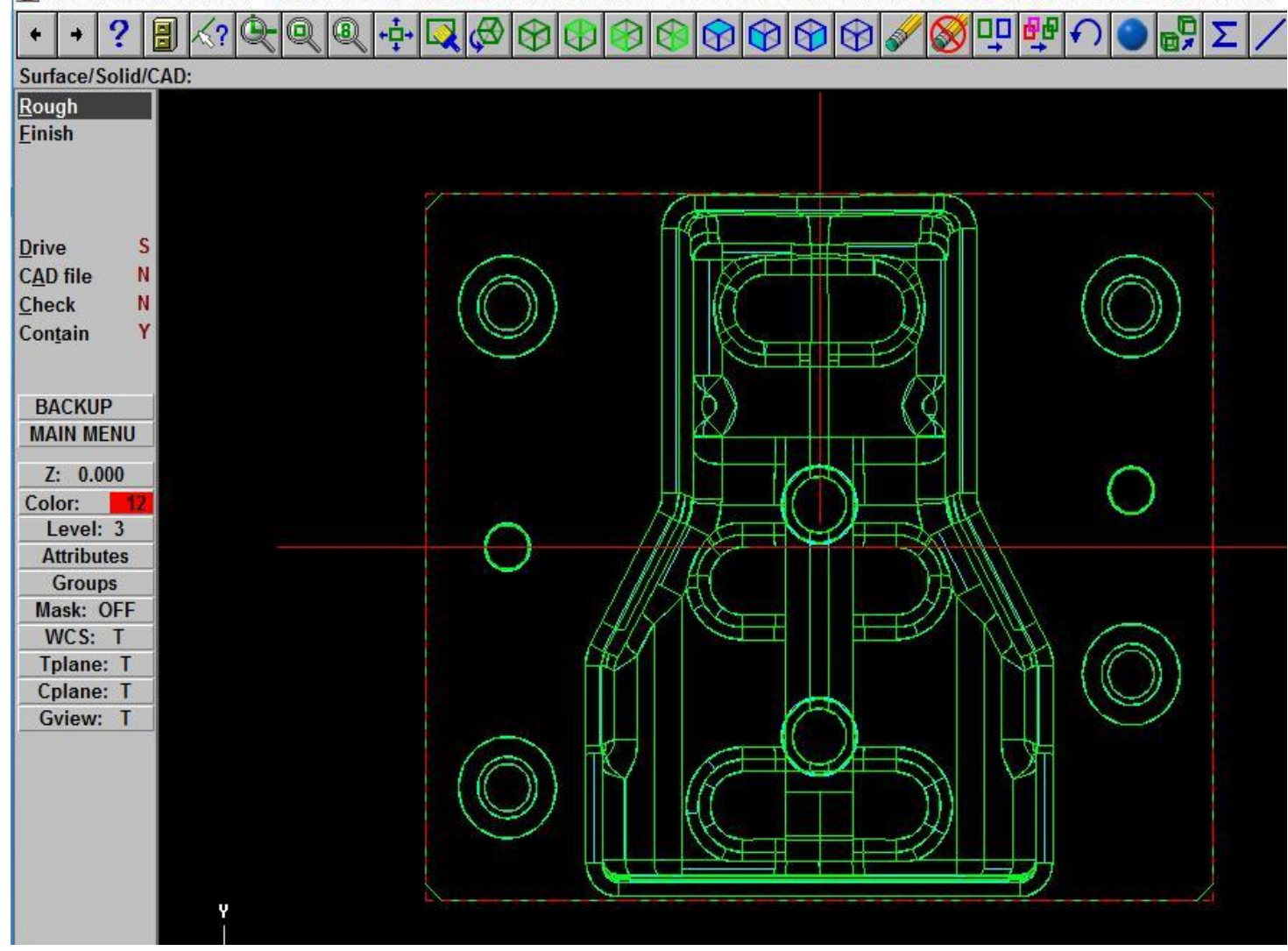


Journal of Mechanical Engineering and Mechatronics

ISSN: 2527-6212, Vol. 3 No. 2

(c) 2018 Pres Univ Press Publication, Indonesia

f. Choose pocket option and choose the line that want to be proceed

10 Mastercam Mill Version 9.1 - D:IADANG CCNCI2017 SIM R4YY4LIBRKT FR PILLAR UPPERI2.6 FORM BEND FLANGEICAMIUNTUK IVAN SUB ASSY LOWER DIE FOR... $+\rightarrow$ ? 圆 K? Surface Roughing:

Parallel

Radial

Project

Flowline

Contour

Restmill

Pocket

Plunge

BACKUP

Z: 0.000

Color: 1

Level: 3

Attributes

Groups

Mask: OFF

WCS: T

Tplane: $T$

Cplane: $\mathrm{T}$

Gview: T

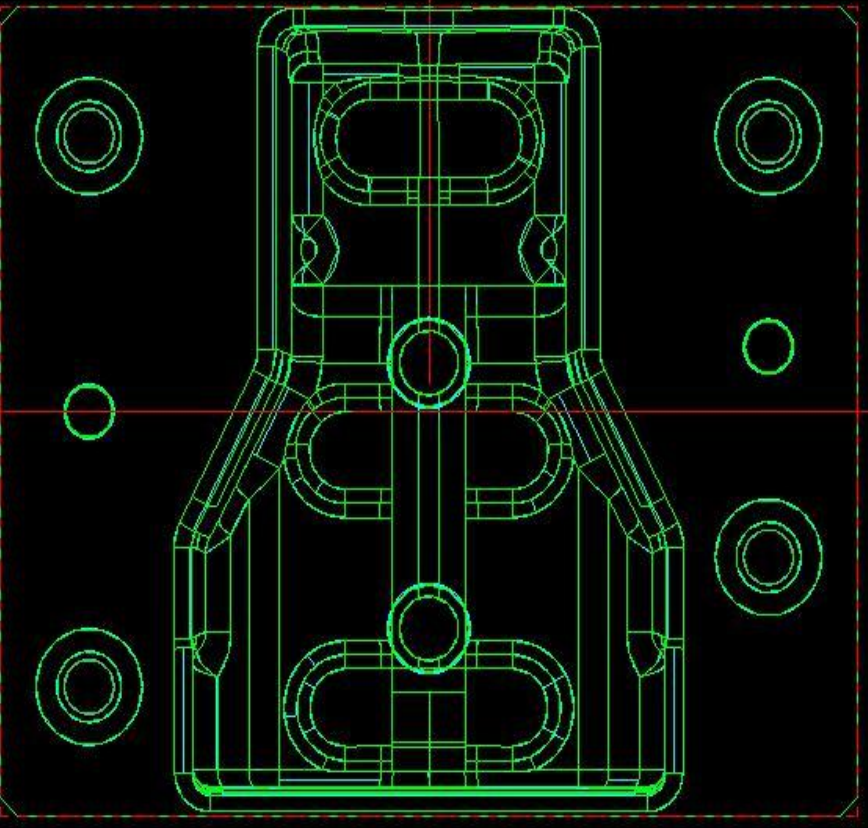

g. Click done

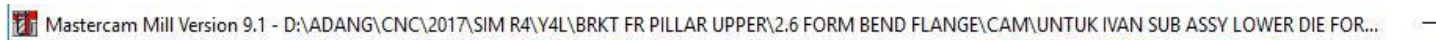
$+1+\mid$ ? 圆 K? Pick Solid Entity:

FromBack $N$

Faces

Solids

Verify

Last

Done

BACKUP

MAIN MENU

Z: 0.000

Color:

Level: 3

Attributes

Groups

Mask: OFF

WCS: T

Tplane: $\mathrm{T}$

Cplane: T

Gview: T

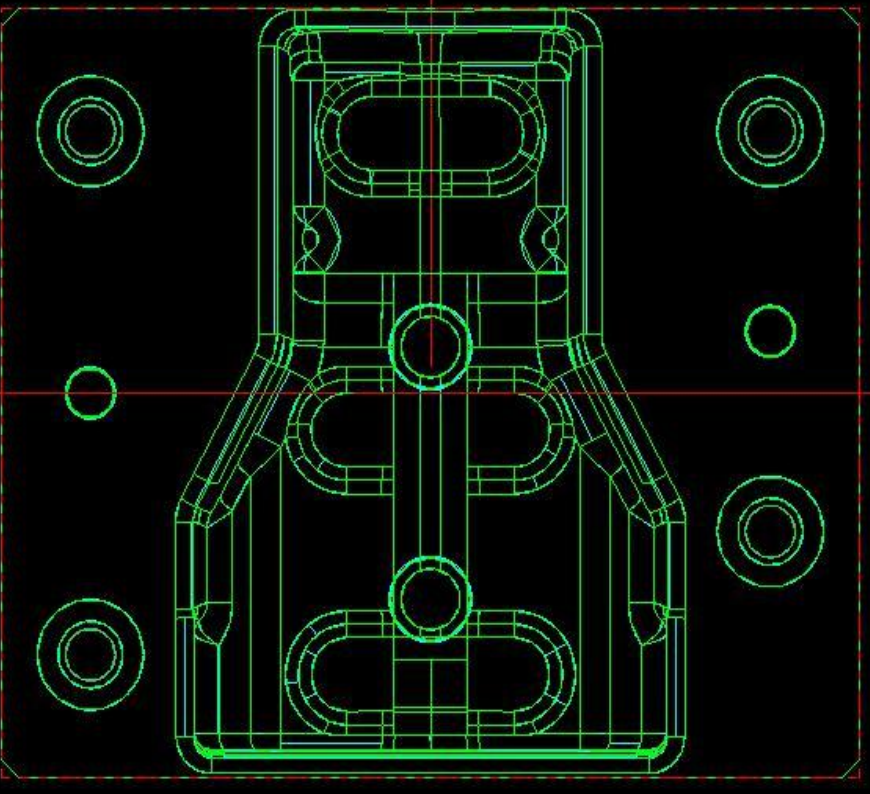


Journal of Mechanical Engineering and Mechatronics

ISSN: 2527-6212, Vol. 3 No. 2

(c) 2018 Pres Univ Press Publication, Indonesia

h. Create new tool for the machining process

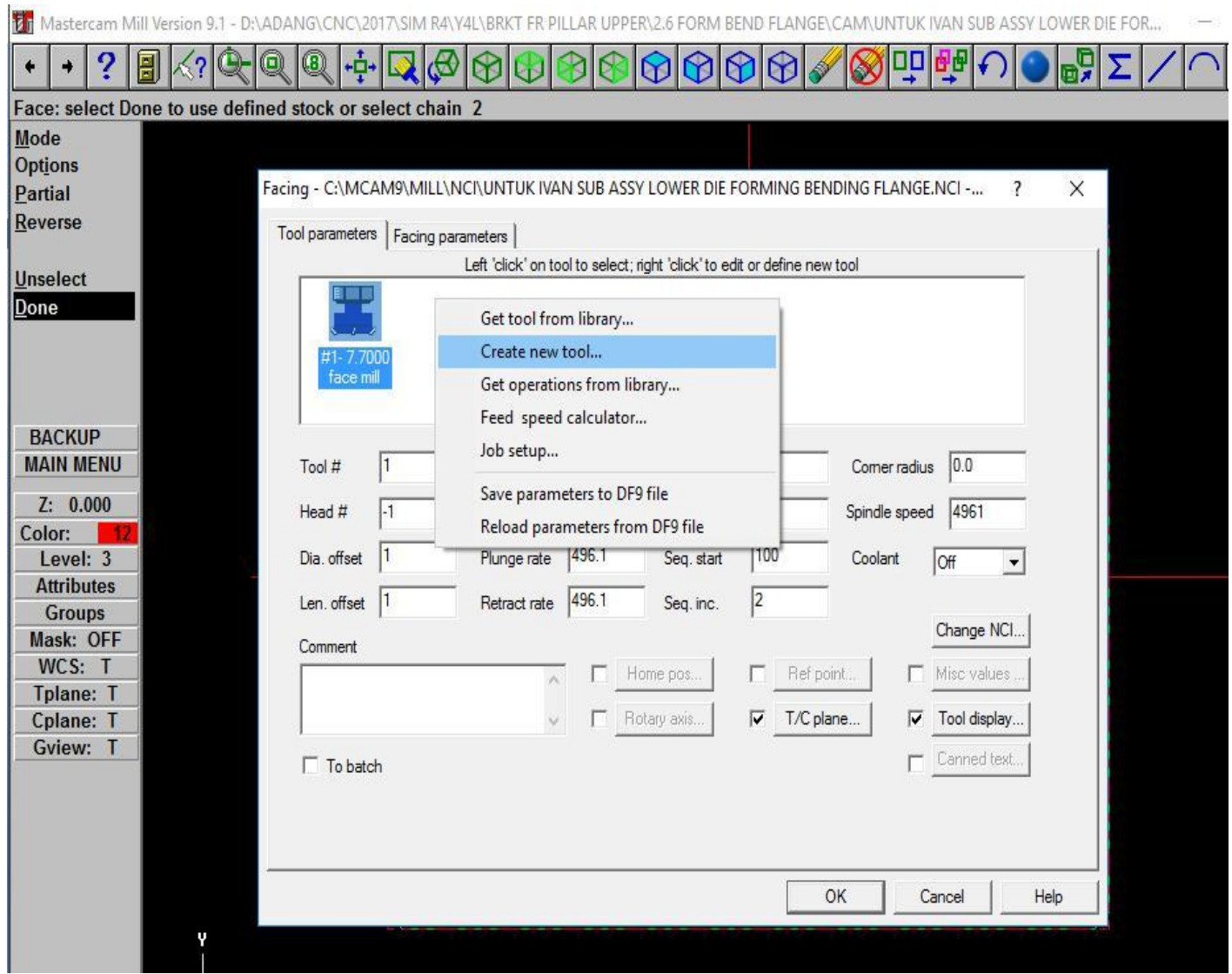

i. Define the tool type that want to be used for machining process

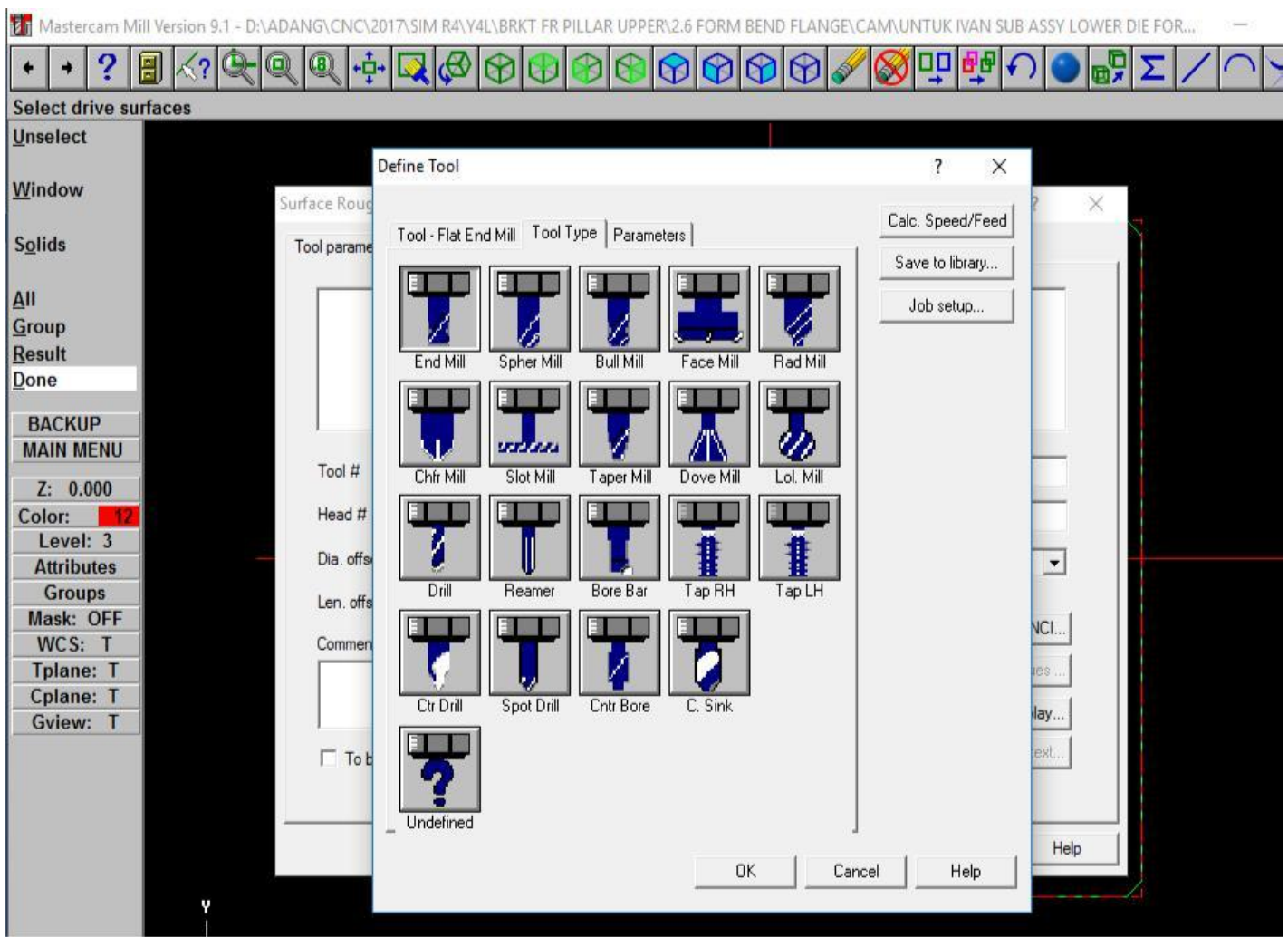


Journal of Mechanical Engineering and Mechatronics

ISSN: 2527-6212, Vol. 3 No. 2

(c) 2018 Pres Univ Press Publication, Indonesia

j. Set the diameter of the tool that needed for machining process

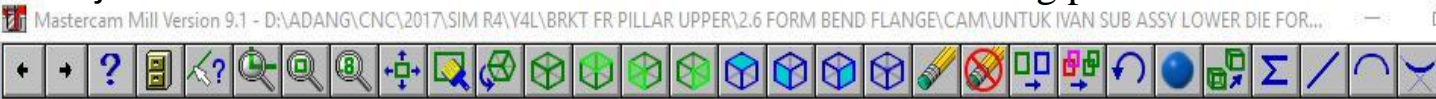

Select drive surfaces

Unselect

Window

Solids

All

Group

Result

Done

BACKUP

MAIN MENU

Z: 0.000

Color: 1

Level: 3

Attributes

Groups

Mask: OFF

WCS: $T$

Tplane: $\mathrm{T}$

Cplane: T

Gview: T

k. Set the total tolerance and maximum stepdown, then click ok

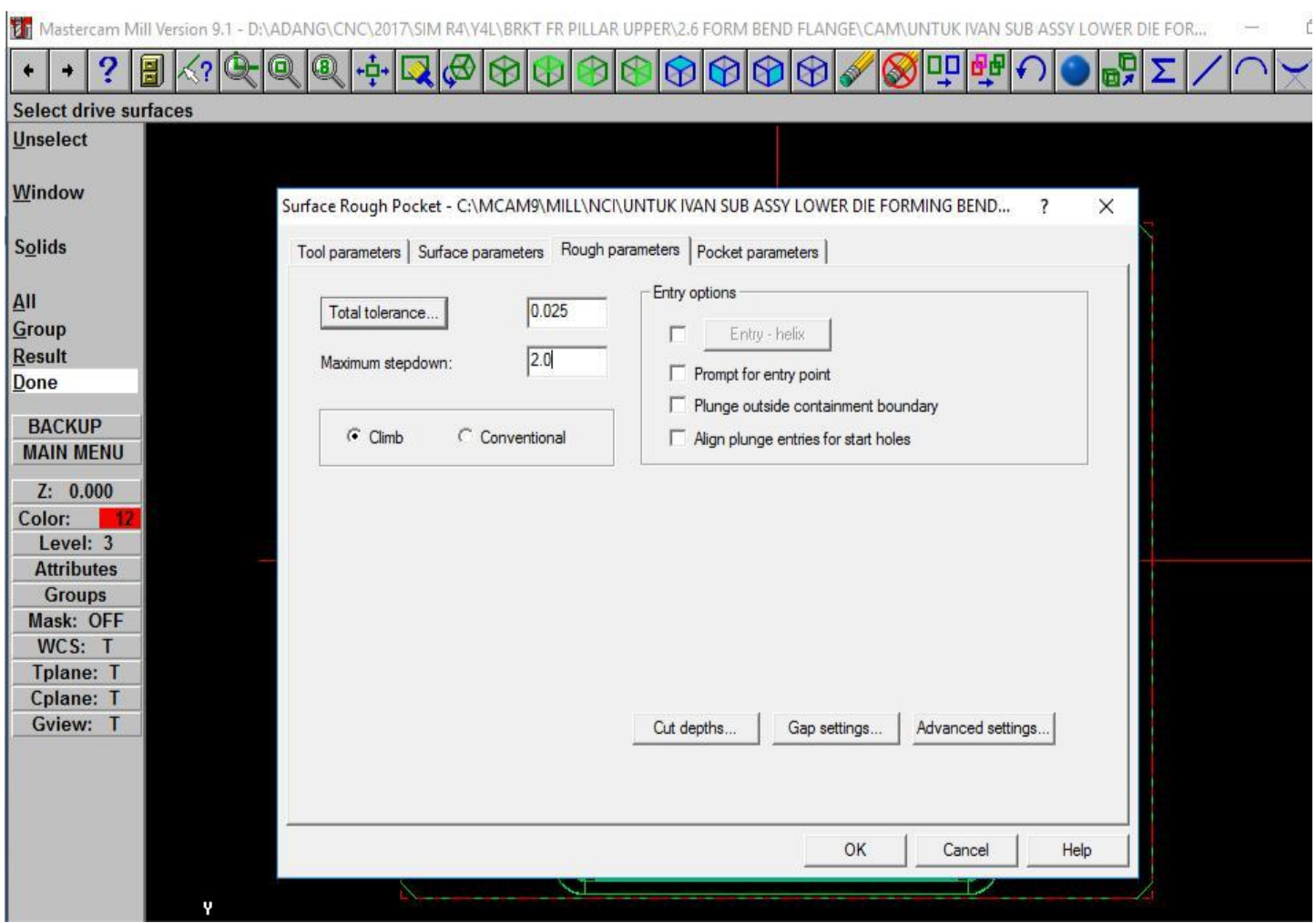




\section{Data collection and analysis}

\section{Parameters Data}

Peck drill - full retract

Table 1 Drill Parameters Data

\begin{tabular}{|c|c|c|c|c|c|c|c|}
\hline $\begin{array}{c}\text { (n)Spindle } \\
\text { speed } \\
\text { (rpm) }\end{array}$ & $\begin{array}{c}\text { Feed rate } \\
(\mathrm{mm} / \mathrm{rev})\end{array}$ & $\begin{array}{c}\text { Tool } \\
\text { dia }\end{array}$ & Clearance & Retract & $\begin{array}{c}\text { Depth } \\
\text { of cut } \\
\text { (mm) }\end{array}$ & $\begin{array}{c}\text { Top } \\
\text { of } \\
\text { stock }\end{array}$ & $\begin{array}{c}\text { Machini } \\
\text { ng time } \\
\text { process } \\
\text { (min) }\end{array}$ \\
\hline 900 & 50 & 7.7 & 180 & 2 & 5 & 162 & 12 \\
\hline 900 & 60 & 7.7 & 180 & 2 & 10 & 162 & 10 \\
\hline 900 & 70 & 7.7 & 180 & 2 & 15 & 162 & 8 \\
\hline
\end{tabular}

Facing

Table 2 Facing Parameters Data

\begin{tabular}{|c|c|c|c|c|c|c|c|}
\hline $\begin{array}{c}(\mathrm{n}) \\
\begin{array}{c}\text { Spindle } \\
\text { speed } \\
(\mathrm{rpm})\end{array}\end{array}$ & $\begin{array}{c}\text { Feed } \\
\text { rate } \\
(\mathrm{mm} / \mathrm{re} \\
\mathrm{v})\end{array}$ & $\begin{array}{c}\text { Tool } \\
\text { dia }\end{array}$ & $\begin{array}{c}\text { Retract } \\
\text { rate }\end{array}$ & Clearance & Depth & $\begin{array}{c}\text { depth of } \\
\text { cut } \\
(\mathrm{mm})\end{array}$ & $\begin{array}{c}\text { Machinin } \\
\text { g time } \\
\text { process } \\
\text { (min) }\end{array}$ \\
\hline 1000 & 1000 & 32 & 1500 & 180 & 161.2 & 2 & 1.43333 \\
\hline 1000 & 1200 & 32 & 1500 & 180 & 161.2 & 4 & 1.21667 \\
\hline 1000 & 1400 & 32 & 1500 & 180 & 161.2 & 6 & 1.05 \\
\hline
\end{tabular}

Surface rough pocket

Table 3 Surface Rough Pocket Parameters Data

\begin{tabular}{|c|c|c|c|c|c|c|c|}
\hline $\begin{array}{c}(\mathrm{n}) \\
\text { Spindle } \\
\text { speed } \\
\text { (rpm) }\end{array}$ & $\begin{array}{c}\text { Feed rate } \\
(\mathrm{mm} / \mathrm{rev})\end{array}$ & Clearance & $\begin{array}{c}\text { Feed } \\
\text { plane }\end{array}$ & $\begin{array}{c}\text { Total } \\
\text { tolerance }\end{array}$ & $\begin{array}{c}\text { Maximu } \\
\mathrm{m} \\
\text { stepdow } \\
\mathrm{n}(\mathrm{mm})\end{array}$ & $\begin{array}{c}\text { Machini } \\
\mathrm{ng} \\
\text { process } \\
\text { time } \\
\text { (min) }\end{array}$ & $\begin{array}{c}\text { Tool } \\
\text { dia }\end{array}$ \\
\hline 650 & 1500 & 180 & 2 & 0.025 & 0.5 & 145 & 33.5 \\
\hline 650 & 1700 & 180 & 2 & 0.025 & 1.5 & 43 & 33.5 \\
\hline 650 & 1900 & 180 & 2 & 0.025 & 2.5 & 23 & 33.5 \\
\hline
\end{tabular}

\section{Summary}

Advantages:

1. The CNC machining cost will be more efficient.

Table 1 lowest machining cost

\begin{tabular}{|c|c|}
\hline Machining process & Lowest machining cost \\
\hline Drill process & Rp 105,700 \\
\hline
\end{tabular}




\begin{tabular}{|c|c|} 
Facing process & $\mathrm{Rp} 82,070$ \\
\hline Surface rough pocket process & $\mathrm{Rp} 313,700$ \\
\hline
\end{tabular}

2. The CNC machining process will take less time to finish.

Table 2 Best machining time

\begin{tabular}{|c|c|}
\hline Machining Process & Best Machining Time (min) \\
\hline Drill process & 8 \\
\hline Facing process & 1.05 \\
\hline Surface rough pocket process & 23 \\
\hline
\end{tabular}

3. The surface of the material that proceed with the fast machining time will be smoother.

Based on the results of data and experimental analysis with reference to the formulation of the problem, this study can be summarized as follows:

1. There is a significant influence on variation of feed rate variation, maximum stepdown variation, and depth of cut variation on the processing time on CNC milling programming by using MasterCAM software.

2. The cost for the machining process on the $\mathrm{CNC}$ milling machine have become more efficient from the effect of the optimized feed rate, maximum stepdown, and the consideration of the tool life time.

3. The result from using the variation of feed rate, maximum stepdown, and depth of cut on the processing time on $\mathrm{CNC}$ milling programming variation are resulting good parameters choice for each machining process by using the optimized feed rate, maximum stepdown, and the consideration of the tool life time.

\section{DAFTAR PUSTAKA}

[1] B. Sentot Wijanarka, Cadcam for CNC milling machine.

[2] Gurel, S, and M.S. Akturk. 2007. Considering Manufacturing Cost and Scheduling Performance on a CNC Turning and Milling Machine. European Journal of Operational Research, Vol. 177: 325-343.

[3] Pinar, Ahmet Murat, and Abdulkadir Gullu. 2005. Time Minimization of CNC Part Programs in a Vertical Machining Center in Terms of Tool Path and Cutting Parameter Criteria. Turkish Journal of Engineering \& Environmental Sciences. Vol. 29: 75-88.

[4] PT. MISUMI INDONESIA. 2017. Material Catalog. Cikarang.

[5] PT. MITSUBISHI. 2017. CNC Milling Tool Catalog. Cikarang.

[6] PT. TRIMITRA CHITRAHASTA. 2016. Machine Operation Calculation. Cikarang.

[7] PT. TRIMITRA CHITRAHASTA. 2017. Module Training. Cikarang. 